\title{
La represión política en Sevilla durante el franquismo, 1940-1951
}

\author{
Aurelio Peral Peral \\ Francoist repression in Seville, 1940-1951
}

\begin{abstract}
RESUMEN
ABSTRACT

Este articulo trata sobre algunos casos, This article deals with some specially especialmente representativos, de la represión franquista llevada a cabo en Sevilla, contra personas civiles juzgadas por Tribunales Militares entre 1940 y

1951, inculpadas de contravenir la legislación vigente mediante hechos de tipo político acontecidos tras la Guerra Civil. Se destacan los elevados castigos a penas de prisión impuestos, en relación con la aparentemente reducida importancia de las acciones llevadas a cabo, por lo que es de considerar que con estas condenas se trataba de coartar la creación de una oposición significativa al régimen.

PALABRAS CLAVE: Unión Nacional, Sevilla, Represión política, Consejos de Guerra, Mallo Fernández, Campos Osaba, Rodríguez Corento. representative cases of Franco's repression carried out in Seville against civil people. These people were judged by Military Courts between 1940 and 1951 and accused of infringement of current legislation trough political facts occurred after the Civil War. It must be highlighted the severe punishments to prison penalties charged, in relation with the apparently few importance of the actions carried out. Thus we must consider that with these penalties they tried to restrict the creation of a significant opposition to Franco's rule.

\section{KEYWORDS:}

Nacional Union, Seville, Political repression, Court-martials, Mallo Fernández, Campos Osaba, Rodriguez Corento.

El rápido triunfo de la rebelión militar en Sevilla en julio de 1936, quedando la capital sometida a las fuerzas que mandaba Queipo de Llano desde el día 20, con la excepción de dos núcleos de resistencia que aguantaron cuatro días más, no estaba en consonancia con la tradición izquierdista de la provincia hispalense, que en las elecciones de febrero 1936 había conocido un espectacular triunfo de los partidos agrupados bajo el Frente Popular, que consiguieron doce de las dieciséis ac-
\end{abstract}


tas de diputados en litigio. (Cuatro de las seis de la capital, $77,5 \%$ de los votos emitidos, y ocho de las diez del resto de las localidades de la provincia, $83,10 \%$ de los votos escrutados). A este resultado se llegó por la crispación y radicalización de las masas obreras sevillanas durante la II República, cuando coincidieron la Gran Depresión mundial y la crisis local ocasionada por la pérdida de los puestos de trabajo que habia generado la Exposición Iberoamericana. Muestra de esta situación son las 14 huelgas generales y las 143 parciales que se sucedieron entre 1931 y 1936.

Por ello Sevilla parecía ser de los lugares más improbables de España donde triunfara una hipotética reacción de las fuerzas de la derecha. Pero, lograda esta victoria, se produjo el rápido desmantelamiento de toda clase de oposición política u obrera, erradicándose cualquier conflictividad por decreto y pasando la ciudad a convertirse en pieza fundamental para la victoria de los rebeldes, gracias a sus aportaciones de material bélico y de tropas. Los líderes de la izquierda, sus dirigentes naturales $u$ oficiales más conspicuos, fueron eliminados físicamente, tuvieron que huir o acabaron encarcelados.

No obstante, tras la puesta en libertad de detenidos que habian formado parte de los movimientos izquierdistas anteriormente a la Guerra Civil, a los que se unieron simpatizantes con su ideario que no tenían estos antecedentes por su juventud $u$ otras circunstancias, se llevaron a cabo varios intentos de construir una oposición estructurada para combatir el franquismo. Intentos que sistemáticamente fueron abortados por la policía, desmontando las incipientes organizaciones que pretendian articular la resistencia política, hasta el punto que, en algunas ocasiones, la detención de los dirigentes más destacados requirió la llegada de militantes procedentes de otros lugares para encabezar esta oposición al régimen.

Sobre estas tentativas de establecer un frente de lucha antifranquista en Sevilla y sobre la represión que las contuvo, mediante sucesivas desarticulaciones de los comités regionales, provinciales o locales, versará el presente artículo, que constituye anticipo de uno de los capítulos de la tesis doctoral que sobre el movimiento obrero en Sevilla durante el régimen de Franco y la época de la Transición, hasta la legalización de los sindicatos con la democracia, estoy llevando a cabo bajo la dirección del profesor Marín Arce.

La represión contra este grupo de personas civiles, que fue juzgado por actividades subversivas realizadas en los años inmediatamente posteriores a la Guerra Civil y que englobamos bajo el adjetivo "políticas", constituye la mayor parte de este trabajo. Entre las transgresiones de que se les acusó, estuvieron en primer lugar, en el tiempo, la solidaridad en la recaudación de dinero con el que auxiliar a los presos políticos y sus familiares. Después los delitos se ampliaron a la difusión de propaganda y noticias contrarias al régimen, la captación de simpatizantes, la formación de comités, los quebrantamientos de condena, el auxilio a malhechores, etc. Los plantes o paros laborales fueron escasos, pues las reivindicaciones obreras, desaparecidos los grandes sindicatos tradicionales, UGT y CNT, se orientaron 
hacia el aprovechamiento de las posibilidades legales, utilizando las lagunas que existían en la legislación vigente. La otrora concienciación de los trabajadores quedó apagada durante más de veinte años, hasta que una nueva generación, que no conoció los horrores de la guerra, llegó a edad laboral.

Esta represión estuvo dirigida fundamentalmente contra los componentes o simpatizantes del Partido Comunista, prácticamente los únicos que constituyeron la oposición sevillana, bien bajo el nombre de este partido o formando parte de Unión Nacional. Para la Brigada Político Social o para la Guardia Civil, no hubo nunca dudas en lo que respecta a su adscripción, comunista, según se observa en la instrucción de los correspondientes procesos.

La época acotada en el título se corresponde con la investigación realizada en el Archivo Histórico del Tribunal Militar Territorial Segundo, donde residía la jurisdicción contra los denominados actos subversivos llevados a cabo por personal civil en la demarcación de la Capitanía General de la 2. ${ }^{a}$ Región Militar, pues después de la Guerra Civil y hasta la promulgación de la Ley 154/63 de 2 de diciembre, que creó el Juzgado y el Tribunal de Orden Público, los infractores por estos delitos eran juzgados en Consejos de Guerra. Los expedientes eran incoados por la Guardia Civil o por la Brigada Político Social, según el ámbito territorial, y el periodo de instrucción era dirigido por un juez militar, cargo que en todos estos años, prácticamente, ostentó el capitán de Infantería, después comandante, Fructuoso Delgado Hernández.

Por lo tanto, aunque condicionados por el deficiente estado de conservación del citado archivo, prácticamente sin clasificar y con sus fondos de muy difícil consecución, accediendo a los documentos que constan en las diligencias de estos procesos puede tenerse una visión tanto del volumen de la oposición como de las infracciones juzgadas, de la gravedad que tenían para el Estado en consonancia con las penas impuestas, de la situación social de la época, etc. En los procedimientos figuran las declaraciones de los imputados ante la policía, Guardia Civil y juez instructor, octavillas, circulares, periódicos y otros escritos, hallados en poder de los encartados o en sus domicilios, las conclusiones del juez instructor, el planteamiento de éste y del fiscal, las alegaciones de la defensa -desempeñada, por supuesto, por un militar-, el acta del juicio y la sentencia del Consejo de Guerra, los expedientes individuales de indultos, las liquidaciones de condena, etc., de cuyo análisis se pueden deducir las características de la represión llevada a cabo en Sevilla contra los opositores al régimen. La represión alcanzó también a otros colectivos que, en función de sus características predominantes y en un ánimo sintetizador, hemos dividido en cuatro grandes conjuntos:

1. El primero de estos grupos fue el que sufrió las represalias por «hechos derivados del Glorioso Movimiento Nacional por el delito de rebelión militar", coletilla que constaba en todas las Ordenes de la Plaza del Gobierno Militar de Sevilla mediante las que se convocaban los Consejos de Guerra a partir de finales de enero 1941. Abarcaban a inculpados no solo de Sevilla, sino de cualquier plaza encla- 
vada en la 2. ${ }^{\text {a }}$ Región Militar, que en 1939 comprendía toda Andalucía. Con anterioridad a dicha fecha funcionaron los tribunales militares permanentes, que quedaron suprimidos por Orden del Estado Mayor de la Capitanía General de 21 agosto 1940, en la que se determinaba que «Las Causas que ante ellos estuvieran pendientes de vista se remitirán, con toda urgencia, a la Auditoría, para dictamen". El volumen de la represión por estos motivos, hasta 1941, no lo podemos establecer, pero para hacerse una idea de su volumen se puede aportar que entre el 24 enero 1941 y el 15 abril 1944, último proceso de este tipo que hemos detectado, (fechas en las que ya habría decrecido fuertemente su número), se realizaron en Sevilla 289 juicios, con 2.185 paisanos encartados.

2. Un segundo grupo lo conformaron los "huidos de la Sierra», o los "bandoleros", terminologías que se utilizaron en los procesos para definir la oposición armada al régimen, según si era en los primeros cuarenta o a partir de 1944. La bibliografía consultada apunta a que esta resistencia en Sevilla estuvo muy lejos de la importancia que tuvo en otras provincias andaluzas, por referirnos a este espacio $^{1}$. La que hubo actuó en las Sierras Norte, y Sur, generalmente constituida por partidas procedentes de provincias limítrofes, como Badajoz, Córdoba, Málaga o Cádiz, que hicieron eventualmente de Sevilla su campo de operaciones. Muchos de sus componentes cayeron en enfrentamientos armados con la Guardia Civil, y lo que he localizado de ellos, hasta ahora, está en noticias indirectas, en procesos contra colaboradores reales o forzados de los resistentes. Es de destacar la angustia que padecieron las personas que estuvieron en contacto con ellos, generalmente las menos favorecidas por la fortuna, que moraban en chozas o humildes casillas en medio de la sierra, dedicándose al pastoreo por cuenta ajena, al carboneo, al aprovechamiento del bosque, etc. A las amenazas, no banales, de represalias por parte de estas partidas si denunciaban su presencia en la zona, hay que añadir los castigos que les eran impuestos por las autoridades si no lo hacían inmediatamente. Y las fuerzas de Orden Público acababan enterándose de estas relaciones, generalmente por los comentarios que algún vecino hacía a otro en lugares públicos, aunque fuera, como hemos podido ver en un caso, varios años después.

3. En tercer lugar hay que referirse a los castigos, por quebrantamiento de condena, a fugados que «redimían su pena por el trabajo» en la $1 .{ }^{\mathrm{a}}$ y $6 .{ }^{\mathrm{a}}$ Agrupación de las Colonias Penitenciarias, campos de concentración ubicados en La Corchuela o Los Merinales, que construyeron el Canal del Bajo Guadalquivir, magna obra de $158 \mathrm{~km}$. de longitud, que puso en regadío 80.000 Has. en la provincia sevillana. Estas fugas tuvieron muy diferente grado de represión: desde fusilamientos en noviembre de 1943 (discrepándose en el número, de dos a seis per-

1 Entre otras, la obra de Francisco MOREnO MuÑoz, La resistencia armada contra Franco. Tragedia del maquis y la guerrilla. El Centro-Sur de España. De Madrid al Guadalquivir, Madrid, Critica, 2001; SECUndino Serrano, Maquis. Historia de la guerrilla antifranquista, Madrid, Temas de Hoy, 2001; MANuEL Pérez Regordán, El maquis en la provincia de Cádiz, Sevilla, Gráficas Rublán, 1987. 
sonas), ordenados por el gobernador militar, hasta reclusiones adicionales a las condenas que cumplían, impuestas en tribunales militares, de 2 meses, de 2 años y 12 años, para otros tantos evadidos, que hemos constatado. La 1. ${ }^{a}$ Agrupación fue la inicial que se constituyó en España, la que más presos acogió y la última que dejó de tener esta clase de penados. En cuanto a su número, la prensa sevillana², en visita de Franco a la zona el 9 mayo 1944, indicó que habian pasado por estas Agrupaciones 5.243 presos, permaneciendo detenidos, en ese momento, 1.800 personas.

4. En cuarto y último lugar, dividido en dos subgrupos, el conjunto de Consejos de Guerra contra el personal militar o el personal civil, acusado de delitos comunes. En el caso de personas civiles estos juicios se producian por la sujeción a la jurisdicción militar de algunos delitos ordinarios, que la legislación vigente adscribia a los tribunales castrenses. (como, por ejemplo, haber atracado a mano armada a una persona civil, al que le quitaron 125 pesetas, amenazándole con una pequeña navaja y un sacacorchos, y que le costó 10 años de prisión a uno de los autores. Otro murió en la cárcel antes del juicio, de tuberculosis, mientras que otros dos coautores, menores de edad, pasaron a disposición del correspondiente tribunal). Idea de la importancia de estos subgrupos pueden darla las siguientes cifras, correspondientes al periodo 1940-1942: 104 juicios contra militares, con 190 encausados, y 42 juicios contra personal civil, con 134 implicados.

Retornando al colectivo que hemos comentado en primer lugar, ya desde octubre de 1942 hay constancia de Consejos de Guerra contra personas civiles, por actividades ilegales realizadas con posterioridad a la contienda civil. De entre los procesos realizados entre dicha fecha y 1951 hemos seleccionado ocho causas de las más reveladoras, bien por el número de personas implicadas, por los castigos dictados, o por la importancia de la desarticulación de las organizaciones clandestinas llevada a efecto por la policía.

\section{CAUSAS 326 Y 327/1940 - CONSEJO DE GUERRA DE 11 DE MARZO DE 1943}

Estas dos causas comprendieron los primeros detenidos tras la Guerra Civil por motivos políticos, que hemos localizado. En este caso no se trató de miembros del PCE, sino del PSOE. De hecho, dos de los condenados, Carmen Monje y Celestino Tejeiro se destacaban, dentro del material expuesto en un reciente certamen celebrado en Sevilla, como paradigmas del Partido Socialista en los primeros tiempos tras la contienda. No obstante la prioridad temporal es cuestionable, ya que hay noticia de la detención en marzo de 1940 de un militante anarquista, acusado del asesinato de un Guardia Civil en enfrentamiento armado, cuando en

2 El Correo de Andalucia y ABC, edición de Sevilla, de fecha 10-5-1944. 
unión de cuatro brigadistas - que resultaron muertos en el tiroteo- iba a ser detenido por preparar un atentado contra Franco, previsto para cuando presidiera la procesión del Santo Entierro el Viernes Santo hispalense de ese año. El legajo correspondiente a este caso no se ha podido localizar.

Los apresamientos a los que nos hemos referido en el primer párrafo de este epigrafe, comprendieron varios encartados, que fueron acusados del reparto de propaganda ilegal firmada por Alianza Democrático-Española. Cinco de ellos resultaron condenados al considerárseles culpables del delito de proposición a la rebelión militar, mientras que de otros cinco el Fiscal retiró la acusación contra ellos.

Los detalles de este proceso, donde no se reflejan los nombres de los absueltos, como será norma en este trabajo, son los siguientes:

\begin{tabular}{|c|c|c|c|c|}
\hline Procesados & Condena & $\begin{array}{l}\text { Petición } \\
\text { M. Fiscal }\end{array}$ & Edad & Profesión \\
\hline Pedro Aguilar García & 5 años & 12 años & 26 & Empleado \\
\hline José Canca López & 3 años & 10 años & 28 & Jornalero \\
\hline Antonio Carrilero Rey & 3 años & 10 años & 28 & Escribiente \\
\hline Carmen Monje Alemany & 6 años & 12 años & 19 & Camisera \\
\hline Celestino Tejeiro Jiménez & 3 años & 12 años & 27 & Charolista \\
\hline
\end{tabular}

La defensa fue ejercida por los tenientes de Infantería José Benito Bueno, Manuel Rayas Ramos y Francisco Zarza del Valle, y por el alférez provisional Joaquín Belmonte García, que solicitaron la absolución de todos los encartados, porque habian actuado por amistad y por la ignorancia de que las «hojillas contenían conceptos injuriosos (...) contra las Instituciones militares». También aducían falta de preparación de los imputados, que no conocían su deber de denunciar la recepción de esas octavillas y, de uno de ellos, se señaló que era «muy aficionado a una intelectualidad que no sabe digerir". Si se querían castigar estos hechos que se hiciera como una actuación derivada del Movimiento Nacional - siguen las alegaciones-, siendo entonces de aplicación los «beneficios de la libertad condicional establecida para esta clase de delitos". El criterio de los defensores se muestra en Zarza del Valle, que inició su alegato señalando: «No puedo por menos de reconocer las grandes dificultades con que tropiezo en la defensa que me ha sido encomendada, derivadas, todas ellas, del afán de persecución que domina en todos los sectores de la vida nacional contra esta clase de delitos, máxime considerando los enormes perjuicios que de dichas ideas se derivaron para el suelo patrio...".

El atestado se inició el 19 de junio de 1940, con la comparecencia ante la Brigada Político Social de Sevilla de un sospechoso, de 58 años de edad, de profe- 
sión peluquero, por presumir que en su establecimiento se habían repartido octavillas de Alianza Democrático-Española, sobre cuya distribución, y fijación en fachadas, la policía sevillana fue alertada desde la Dirección General de Seguridad. Desgraciadamente para esta persona, en el registro que efectuaron en su domicilio encontraron una escopeta de dos cañones, sin licencia ni guía de armas. Además en él concurrían los agravantes de haber pertenecido antes de la Guerra Civil al Partido Radical y sido masón, grado 3 en la Logia España y Trabajo, aunque causó baja en ella antes del 18-7-1936 por falta de asistencia a las reuniones y por el impago de cuotas, y a pesar de hacer en su día la retractación ordenada por las autoridades «nacionales». Ingresado en la Prisión Provincial de Sevilla fue puesto en libertad provisional con fecha 9 de diciembre de 1940, no llegando a ser juzgado pues falleció el 17 de mayo del año siguiente: su caso "fue sobreseído" quince meses después. El arma incautada la habría comprado a un sargento de la Legión que pasó por su barbería hacía unos dos años, no gestionando la documentación legal exigida porque con sus antecedentes políticos sabía que no se la iban a dar. En su declaración informó que solo llegó a su poder una octavilla, recibida de su yerno, - que fue absuelto en el proceso- que trató como una curiosidad, y como tal la comentó con algunas personas, según su declaración, para significar el valor y audacia de algunos elementos "que todavía eran capaces de fomentar una propaganda tan peligrosa".

El 28 de junio se presentó al sumario una nueva hoja de propaganda, «impresa con caracteres mecanográficos en papel rojo-grosella" (casi morado, según se ve en el atestado), en la que se decia que "nuestra propaganda ha sido descubierta» pero que no importaba, que cada compañero que recibiera una de estas octavillas debía hacer una copia para hacerla llegar a manos "del amigo, del compañero, del trabajador de la ciudad, del campo, del empleado, del soldado y de todo aquel que se sienta libre", para "desprestigiar al Gobierno del Generalote", utilizando como argumentos en su difusión «la no beligerancia, el arrebato de Tánger a los hombres libres, la carencia de artículos alimenticios, sobre todo el pan, la indisciplina dentro de la Falange, el descontento Tradicionalista, la futura entrada de España en guerra....".

Pedro Aguilar Garcia fue detenido en relación con este nuevo volante, por existir "probables sospechas" de estar complicado, o conocer algo de su existencia. Registrado su domicilio y el local donde estaba instalando una agencia de publicidad, se le encontraron hojas de papel, de factura, color y aspecto idéntico a aquel en que estaba confeccionada la propaganda, sobre las que manifestó que no podía precisar su procedencia, suponiendo que en ellas le envolverían alguna de las compras realizadas en unas papelerías sevillanas para su negocio. También se le encontraron en su domicilio, y así se refleja en la correspondiente acta, El eterno retorno y El epistolario, de Nieztsche, El triunfo y la tragedia de Erasmo de Rotterdam, El amor libre, de Diderot, Demián, de Hermann Hesse, Las ilusiones, de Hippolyte Taine, Confesiones, de Verlaine, El pescador de esponjas, de Panait Istrati, ("libros de literatura marxista", según consta en las conclusiones del fiscal ju- 
rídico militar), y, de su puño, unos apuntes sobre las opiniones de Nieztsche, los manuscritos a lápiz, en hojas de un cuaderno escolar, de dos novelas de su creación: Boinas Rojas, (105 hojas) censurando, según los agentes que firmaban este acta, "los postulados del Glorioso Movimiento Nacional» y No puede ser, "concebida en términos libertarios». También se le encontraron un ejemplar de la Gaceta de Madrid, de 9 de diciembre de 1931 (publicación de las Cortes Constituyentes de la II República), un boletín de propaganda británica antialemana de 20 de abril de 1940, y un ejemplar de la conferencia que el detenido dio en el Ateneo Popular, del que fue miembro fundador, a mediados de 1936.

El propio Juez instructor, que a diferencia del resto de las Causas que se verán fue el comandante de Infantería Francisco Zambrana Hidalgo, visto el escaso relieve de los delitos imputados, informó favorablemente las instancias de concesión de libertad provisional que cursaron todos los encausados, a título individual. El auditor regional dio también su aquiescencia, que suscribió el Capitán General, por lo que todos los detenidos quedaron en dicha situación, entre octubre 1940 y enero 1941. Tras la sentencia, los condenados a cárcel fueron de nuevo detenidos e ingresados en la Prisión Provincial de Sevilla.

\section{2." CAUSA 1546/1941. CONSEJOS DE GUERRA DE 9 DE OCTUBRE DE 1942 Y 20 DE OCTUBRE DE 1945}

En esta causa, dividida como se indica en dos Consejos de Guerra, es de destacar el número de encartados, la dispersión geográfica de los mismos dentro de Andalucía occidental, y la arbitraria división de los detenidos en dos procesos tan distantes en el tiempo que, al juzgar antes a los que se consideraban los más importantes de los acusados, acabó por perjudicar a los que fueron incorporados en el segundo grupo, los estimados como menos relevantes. También es de subrayar la decisión del Ministerio Fiscal, que solicitó el indulto para los condenados en el primero de estos dos juicios, justificándolo en la rigurosidad de la sentencia. Todos estos motivos hacen que esta causa haya de considerarse como muy destacada.

Entre los meses finales de 1941 y primeros de 1942 se produjo un importante número de detenciones en Sevilla y otras provincias andaluzas, en total 170 personas, como consecuencia del descubrimiento por la Brigada Político Social de Madrid, según consta en el legajo correspondiente, de una "vasta organización de carácter subversivo" en la Segunda Región Militar, estando su cabecera en SeviIla. Sus actividades «iban encaminadas a derrocar el régimen actual de España y su Caudillo", mediante la reconstitución del PCE y de las Juventudes Socialistas Unificadas pretendiendo, al mismo tiempo, llevar a cabo una eficaz ayuda pro-presos (antes denominada socorro rojo).

El proceso es recordado como el de las "centenas", por ser éste el sistema de sorteos que se efectuaban para recabar fondos de diversas personas, algunas de 
ellas sin más ánimo que el puramente caritativo; fondos que se añadian a los obtenidos por donaciones espontáneas, o periódicas, de simpatizantes, que resultaban insuficientes para atender las necesidades de los presos y del propio Partido Comunista. Por ejemplo, en algunos de los boletines de Mundo Obrero de estos años, que hemos visto dentro de los expedientes procesales, se insistía en la carencia de dinero suficiente para financiar su tirada. En estas "centenas", según algún protagonista, se rifaban diez duros. Pero, por testimonios orales, es más conocido el sorteo de una lámpara de "hilo", confeccionada por los internados en la Prisión Provincial de Sevilla, aunque parece ser que este premio nunca llegó a ser físicamente real. Para una siguiente ocasión, que ya no se llevó a efecto, el estímulo iba a consistir en "cortes" de trajes, según declaró el detenido que tenía encargada la sección de Finanzas, dentro de las Juventudes Socialistas Unificadas.

Para la captación de simpatizantes, uno de los sistemas consistía en la introducción de miembros del partido en clubes deportivos. En este contexto, a lo largo del proceso, se citan el de la Puerta Osario, el Viñas, etc. Se añadia al proselitismo más habitual y efectivo hecho entre compañeros de trabajo o de mili, o entre amigos y vecinos, conociendo previamente sus ideas o su posible desavenencia con el régimen por antecedentes familiares. Normalmente se empezaba especulando con la difícil situación económica por la que atravesaba España, y en función de la respuesta obtenida, expresa o tácita, ya se pasaba a hablar de política y de acciones. Era entre este público donde se vendía la mayoría de las papeletas de las rifas.

Al procedimiento judicial militar correspondiente a las expresadas detenciones se decidió darle la mayor rapidez, para ejemplaridad. Pero como se carecía de medios suficientes, se "acordó por la Autoridad Judicial de la Región" (el Capitán General) separar el proceso en dos Consejos de Guerra, como ya se ha comentado: uno contra los «elementos responsables principales" y otro contra los que aparecían «acusados en autos con una menor actuación y presunta responsabilidad", como consta en sendas diligencias de 8 y 12 de mayo de 1944. En el cuadro que a continuación se inserta, figuran los procesados en el primero de ellos, reunido en Sevilla, el 9 octubre 1942, donde no se hace distinción de la plaza de su domicilio, por cuanto no se ha localizado la pieza que contiene la instrucción, el juicio y la sentencia. Por ello, los datos correspondientes se han obtenido entresacándolos de la diversa documentación que figura en el segundo de los Consejos de Guerra. No se reflejan los detenidos que obtuvieron la libre absolución, que fueron tres en el proceso inicial y diecinueve en el complementario. Otros once reos obtuvieron la libertad definitiva con todos los pronunciamientos favorables. El delito imputado fue el de "espionaje".

Los datos correspondientes al primer juicio son los que siguen: 


\begin{tabular}{|c|c|c|c|}
\hline Procesados & Condena & Notas & Fecha libertad \\
\hline Milagros Alcalá Balaguer & 6 años & (c) & $15-2-46$ \\
\hline Rosa Alcalá Balaguer & 1 año y $6 \mathrm{~m}$. & & $27-3-43$ \\
\hline Carlos Bald. Ciudad López & 6 años & (c) & $17-12-46$ \\
\hline Felipe Chica Barruz & 6 años & (c) & $18-7-46$ \\
\hline Francisco Correa Lorenzo & 10 años & (a) & $22-11-46$ \\
\hline Máximo de Mora Barrientos & 8 años & (c) & $19-7-46$ \\
\hline Victoria Fernández Castillo & 6 años & (c) & $24-10-45$ \\
\hline Salvador Galiana Serra & 30 años & (d) & $28-9-47$ \\
\hline Faustino García Martín & 30 años & (c) & $19-7-48$ \\
\hline Joaquín Luna Nieto & 1 año & & $4-1-43$ \\
\hline Diego Montero Castro & 8 años & (c) & $28-7-48$ \\
\hline José Muñoz Sánchez & 30 años & (b) & $28-4-48$ \\
\hline Rosario Navarro del Saz & 8 años & (c) & $23-12-47$ \\
\hline Felipe Neira Vaquero & 4 años & & $2-3-44$ \\
\hline Ramón Parodi Martínez & 2 años & & $7-8-43$ \\
\hline Joaquín Payá Riera & 30 años & (c) & 2-9-44 (Huido) \\
\hline Rafael Pérez Carrillo & 8 años & (c) & 14-12-42 (Fallecido) \\
\hline Juan Pérez Ollero & 10 años & (c) & $28-7-48$ \\
\hline José Ríos Cruz & 30 años & (c) & $19-7-48$ \\
\hline Dolores Romero Cachinero & 2 años & & $19-11-43$ \\
\hline Josefina Vallejo Prada & 6 años & (c) & $24-10-45$ \\
\hline Juan Vázquez Rivas & 6 años & (c) & $8-10-47$ \\
\hline \multicolumn{4}{|c|}{$\begin{array}{l}\text { El Ministerio Fiscal solicitó la pena de } 17 \text { años y } 4 \text { meses de cárcel. El condenado gestionó acogerse } \\
\text { al indulto decretado en 9-10-1945, en forma individual, siéndole concedido. } \\
\text { Para este imputado, el Ministerio Fiscal pidió la pena de muerte. El condenado requirió acogerse al } \\
\text { indulto de 9-10-1945, siendo admitido en sus beneficios. } \\
\text { Se incluyó de oficio, en petición del fiscal, para ser admitido a los beneficios del expresado indulto. } \\
\text { Esta petición tiene fecha 1-7-1948,aprobándose la concesión por el Capitán General de la 2.: Región } \\
\text { Militar el día } 8 \text {. } \\
\text { Solicitó la aplicación del indulto de 9-10-1945, individualmente, lo que le fue aceptado. }\end{array}$} \\
\hline
\end{tabular}

Las motivaciones que inspiraron al fiscal la petición de gracia, fueron que «el delito perseguido fue secuela de nuestra guerra de liberación"; que su principal desarrollo "tuvo lugar durante ella»; que las penas que se aplicarían en la fecha de su petición, si el caso surgiese en ese momento, no tendrían paridad con las adoptadas; "que con razón debe de estimarse rigurosa la sentencia" y que una interpretación amplia del decreto del indulto hacía extensible la aplicación de sus beneficios a todos los condenados, salvo, claro está, a los que ya cumplieron sus penas y a los ya acogidos a él, (que arriba han quedado reflejados), que se adelantaron a sus compañeros, a nuestro entender, por haber podido disponer de mejor asesoramiento legal. No cabía mantener en prisión al resto de los inculpados 
en el mismo proceso, cuando se había puesto en libertad a parte de ellos, y no precisamente los condenados a penas inferiores, pues reclusiones de 30 años se saldaron con menos de 6 años de prisión. El efecto de la petición de gracia, en resumen, quedó limitado a cuatro de los reclusos, ya que de los catorce penados que comprendia, uno falleció en 1942 (en la Prisión Provincial de Sevilla, cuando contaba con 20 años de edad), otro se fugó en septiembre de 1944 del destacamento penal de Gardeny (Lérida) y ocho accedieron a la libertad con antelación a la petición. No obstante, una vez concedida la libertad, las instrucciones que se pasaban por las autoridades eran las de ejercer una severa vigilancia sobre los indultados "en todos los aspectos de su vida" (como remarca un oficio de la Guardia Civil de Espejo). Esto era llevado a la práctica de tal forma que uno de los señalados antes, Máximo (o Maximino) de Mora, se dirigió al Capitán General de la Segunda Región Militar el 29 de enero de 1949, quejándose de que la Brigada Político Social de Sevilla le obligaba a presentarse todos los meses, cuando le constaba documentalmente que su responsabilidad quedó liberada definitivamente al cumplir la condena. El auditor de Región informó a la expresada autoridad militar que la reclamación era procedente, por lo que se ordenó que tanto éste como el resto de los implicados, al haber cumplido la pena, "no pueden ser obligados a presentaciones de ningún género ante las Autoridades policiacas...", pero todo ello "sin prejuzgar de la esfera de acciones que tengan las Autoridades Gubernativas".

La segunda parte de la Causa 1546/41 fue dirimida en Consejo de Guerra tres años después del que se siguió contra los más sobresalientes de los detenidos. En este juicio, realizado el 20 de octubre de 1945, solo hemos incluido los acusados domiciliados en Sevilla. El detalle del resultado figura en el cuadro siguiente:

\begin{tabular}{llrrlll}
\hline Procesados & Condena & $\begin{array}{c}\text { Petición } \\
\text { M. Fiscal }\end{array}$ & Edad & Profesión & $\begin{array}{c}\text { Exceso } \\
\text { cumplimiento } \\
\text { condena }\end{array}$ \\
\hline Eduardo Alvarez Heller & 5 años & 18 años & 27 & Empl.oficina & \\
Benjamín Arcas Medina & 3 años & 8 años & 34 & Músico & 1 año $2 \mathrm{~m} .11 \mathrm{~d}$. \\
Patrocinio Castro Montero & 3 años & 8 años & 20 & Camisera & 1 año $2 \mathrm{~m} .7 \mathrm{~d}$ \\
Tomas Ciorraga laguna & 3 años & 8 años & 33 & Jornalero & 1 año $2 \mathrm{~m} .7 \mathrm{~d}$. \\
José de Coc Martínez & 5 años & 20 años & 52 & Jornalero & \\
Dolores Santos Romero & 3 años & 30 años & 34 & Sus labores & 11 meses 17 dias \\
Antonio Galán Rodríguez & 3 años & 12 años & 38 & Embalador & 1 año $2 \mathrm{~m} .18 \mathrm{~d}$, \\
Antonio García Martínez & 3 años & 8 años & 24 & Músico & 1 año $2 \mathrm{~m} .7 \mathrm{~d}$. \\
José Hinestrosa Velasco & 5 años & 18 años & 49 & Mecánico & \\
Manuel Jiménez Galán & 5 años & 8 años & 47 & Practicante & \\
Francisco Jiménez Jiménez & 3 años & 12 años & 37 & Herrero & 1 año $2 \mathrm{~m} .11 \mathrm{~d}$. \\
Antonio Martín Fernández & 6 años & 8 años & 23 & Depdte.comest. & \\
Heliodora Mateos Fernández & 3 años & 18 años & 26 & Sus labores & 1 año $2 \mathrm{~m} .7 \mathrm{~d}$. \\
Manuel Mayo Muñoz & 6 meses & 8 años & 37 & Cerrajero & 3 años $8 \mathrm{~m} .13 \mathrm{~d}$ \\
Francisco Morillo Carretero & 8 años & 30 años & 23 & Escribiente &
\end{tabular}


(Continuación)

\begin{tabular}{|c|c|c|c|c|c|}
\hline Procesados & Condena & $\begin{array}{l}\text { Petición } \\
\text { M. }{ }^{\circ} \text { Fiscal }\end{array}$ & Edad & Profesión & $\begin{array}{c}\text { Exceso } \\
\text { cumplimiento } \\
\text { condena }\end{array}$ \\
\hline Juan Mudarra Velasco & 1 año & 8 años & 36 & Mecánico & 2 años $11 \mathrm{~m} .25 \mathrm{~d}$ \\
\hline Angel Pastor Ochoa & 8 años & 8 años & 25 & Soldado & \\
\hline Luis Pérez Rojas & 3 años & 8 años & 27 & Comercio & 1 año $2 \mathrm{~m} .21 \mathrm{~d}$. \\
\hline Ana Ponce Barneto & 1 año & 8 años & 19 & Sus labores & 3 años 2 m. 19d. \\
\hline José Prado Maqueda & 6 meses & 8 años & 24 & Metalúrgico & 3 años $8 \mathrm{~m} .16 \mathrm{~d}$ \\
\hline Luis Prieto Gómez & 5 años & 20 años & 33 & Embalador & \\
\hline Antonio Rodríguez Espina & 6 meses & 8 años & 46 & Jornalero & 3 años $8 \mathrm{~m} .5 \mathrm{~d}$. \\
\hline $\begin{array}{l}\text { Manuel Romero Martín } \\
\text { Salvador Ruiz Soler }\end{array}$ & $\begin{array}{l}3 \text { años } \\
3 \text { años }\end{array}$ & $\begin{array}{l}30 \text { años } \\
8 \text { años }\end{array}$ & $\begin{array}{l}33 \\
28\end{array}$ & $\begin{array}{l}\text { Jornalero } \\
\text { Delineante }\end{array}$ & $\begin{array}{l}3 \text { años } 11 \mathrm{~m} .13 \mathrm{~d} \text {. } \\
1 \text { año } 7 \text { días. }\end{array}$ \\
\hline Celestino Tejeiro Jiménez & 6 meses & 8 años & 28 & Charolista & 3 años, $7 \mathrm{~m} .6 \mathrm{~d}$. \\
\hline
\end{tabular}

Las edades y profesiones señaladas eran las que tenían los imputados en la primera comparecencia que prestaron ante la policia, entre septiembre y diciembre de 1941. El exceso de tiempo de reclusión, en relación con las penas definitivas, está obtenido de las hojas de liquidación de condena emitidas por el Juez instructor el 25 de enero de 1946. Hay que destacar que las fechas de comienzo de la prisión preventiva de los encartados reflejadas en dichas hojas, difieren de las señaladas como de ingreso en la Prisión Provincial de Sevilla, pues las primeras se corresponden con las de la detención y retención en los calabozos de la policía. Se detectan así permanencias en las dependencias policiales superiores a un mes. Por otra parte, no todo el tiempo señalado como exceso de cumplimiento de la sanción significa estancia en la cárcel, pues dentro de este periodo el detenido podría estar en arresto atenuado en su domicilio (computable para el cumplimiento de la sentencia), con la obligatoriedad de presentarse periódicamente ante las autoridades policiales, como se ha podido comprobar documentalmente en varios casos.

En conjunto, el fiscal de este Consejo de Guerra solicitó penas por un total de 480 años para todos los inculpados domiciliados en Sevilla, entre los que resultaron diecinueve absueltos, para los que había pedido sendas condenas de 8 años, por no haber considerado la «magnanimidad del Caudillo al promulgar Decretos y Leyes de indulto para quienes delinquieron, incluso por segunda vez". En total acabaron dictándose sentencias por un total de 84 años. Para los ciento diez encartados que fueron juzgados esta vez, pues abarcó a todos los detenidos de las diversas provincias, de los que cuarenta y cuatro eran sevillanos, solo hubo un defensor, el capitán del Cuerpo de Mutilados Eugenio Garrido Valero, que pidió para todos la absolución, entre otras cosas porque, a) «los hechos enjuiciados carecían de la importancia que a primera vista pudiera creerse que tenían»; b) "dada la insignificante categoría social de todos los procesados (...) no podía admitir que ocupasen (...) puestos tan relevantes como los que se les atribuían»; c) 
ante la imposibilidad de "hacer plena luz de los hechos" la equidad exigía absolver antes a un culpable que condenar a un inocente"; d) que los que compraron papeletas de las rifas era por afán de lucro, como podían haber comprado Lotería, o porque apelaron a su caridad para socorrer a enfermos o presos, etc.

La sentencia, en su primer resultando, determinó que se habían descubierto actividades subversivas encaminadas a la creación de una estructura comunista de tipo clandestino, "sin haberse podido determinar de una forma perfecta si dicha organización llegó a funcionar, ni tampoco concretarse de una manera exacta y real la actividad de cada una de las personas que han resultado ligadas a la misma o si el descubrimiento de tal organización fue la causa que impidiera su funcionamiento...". Lo cierto era que se detuvo a una serie de personas "ligadas o al menos complicadas con la referida organización clandestina" y que su actuación era de «abierta oposición con el actual régimen que acaudilla el Generalísimo Franco».

\section{CAUSA 337/1944. CONSEJO DE GUERRA DE 29 DE NOVIEMBRE DE 1945}

El motivo de comentar esta causa es haber aparecido, por primera vez hasta ahora, la imposición de penas de muerte en la sentencia del Tribunal Militar, aun cuando posteriormente fueran conmutadas por el Jefe del Estado por la inferior en rango.

El proceso alcanzó, según la sentencia, a las personas que integraban el comité regional del Partido Comunista en Andalucia, del que dependian los provinciales y otros de carácter local en pueblos. La organización descubierta por la policía, se denominaba "Partido de Unión Nacional", que encubría, siempre según la sentencia, a otra "francamente soviética", que utilizaba en su propaganda "vocablos (...) buscados de intento para atraer incautos" y cuyo propósito era mantener un estado de rebeldía contra las instituciones de la Nación, desprestigiándolas con "calumnias y falsos decires al objeto de sembrar la discordia entre los españoles" (frase esta última copiada del alegato del Ministerio Fiscal).

Según una octavilla existente dentro del legajo de este procedimiento, fechada en diciembre 1943, la Junta Suprema de Unión Nacional se había constituido en Madrid, en septiembre de ese año, por dirigentes republicanos, socialistas, comunistas, vascos, y de UGT y de CNT, para organizar la lucha de todos los patriotas, con objeto de derrocar a Franco y su Falange, instaurando a continuación un gobierno en el que estuvieran representadas todas las fuerzas de izquierdas y derechas, en un programa que tendría como objetivo romper los lazos de España con Alemania, depurar de falangistas el aparato del Estado, "principalmente en el Ejército", conceder la amnistía, reestablecer las libertades democráticas básicas y convocar elecciones a una Asamblea para la promulgación de una Constitución libre $e$ independiente. En esta hoja se mostraba la esperanza en que estos objetivos 
estaban cercanos, dado el esfuerzo de los ejércitos anglo-ruso-americanos que estaban consiguiendo derrotar al "monstruo Hitler», y porque Franco no se mantendría tras la victoria de las Naciones Unidas. Se pedía la ayuda de todos los españoles, sin distinción de ideologías, para un aporte de víveres, de ropas y de dinero para los presos y sus familias en las fiestas navideñas que se avecinaban.

El detalle de los imputados, y sus condenas, en este proceso, es como figura en el siguiente cuadro:

\begin{tabular}{lcccc}
\hline Procesados & Condena & $\begin{array}{c}\text { Petición } \\
\text { M.º Fiscal }\end{array}$ & Edad & Profesión \\
\hline José Blanco Brualla & Muerte & Muerte & 29 & Maestro Nacional \\
Manuel Castro Campos & Muerte & Muerte & 44 & Ceramista \\
Bartolomé García Belmonte & 2 años & 12 años & 30 & Jornalero \\
Florentino Muñoz Alvarez & 2 años & 12 años & 31 & Jornalero \\
José Palma Salas & 2 años & 30 años & 27 & Empleado Azucarera \\
Juan Ramírez Martínez & 2 años & 12 años & 36 & Jornalero \\
\hline
\end{tabular}

El defensor de los seis reos fue el teniente Manuel González Castellano, que solicitó penas mínimas (6 meses) para Blanco y Castro, como autores de un delito contra la Ley de Seguridad del Estado, y la libre absolución para los otros cuatro encartados. Las condenas a muerte que al final se impusieron fueron por el delito de adhesión a la rebelión militar y las de dos años, por el de auxilio a la misma. El Capitán General de la Región prestó su conformidad a las penas expuestas el 19 diciembre, dejando en suspenso la ejecución de las dos capitales hasta que el Gobierno se diera por enterado. Conocida la sentencia por la máxima autoridad nacional, se conmutaron las dos penas de muerte por la inferior en grado, 30 años de reclusión, según certificaba el 4 de febrero de 1946 la Auditoría Jurídica del Ministerio del Ejército.

La acusación concreta contra Castro Campos, fue la de haber desempeñado el cargo de secretario general en Andalucía del Partido Comunista, desde 1942 hasta febrero 1944, siendo el máximo responsable de dicha región y el enlace con la delegación nacional en Madrid, como admitió en diversas declaraciones ante el juez instructor. Se consideraba probada dicha imputación, agregándose que ostentando dicho cargo realizó «una brillante campaña de captación de adeptos" con la consiguiente e indispensable recogida de cuotas en metálico, la adquisición de una máquina de escribir y de otra multicopista para la tirada de propaganda y de ejemplares de periódicos clandestinos tales como Mundo Obrero y Reconquista de España. También habría logrado formar comités provinciales en Córdoba, Granada, Jaén, Huelva y Málaga. Era conocido por los nombres simbólicos de "Luisa" y "Bartolo", y tenía antecedentes penales por haber sido condenado a seis meses de cárcel en octubre 1941, por auxilio a la rebelión. El delito de Blanco Brualla, tras 
pasar a España procedente de Francia, una vez instruido convenientemente para la ejecución de trabajos clandestinos del "Partido de Unión Nacional o Comunista" (según consta textualmente en la sentencia), fue sustituir a Castro Campos en el puesto de secretario general regional del PCE, cuando este último abandonó Sevilla para eludir su inminente detención.

El inicio de las actuaciones partió de un escrito de la Dirección General de Seguridad, fechado el 11 de enero de 1944, en el que se manifestaba que de las declaraciones de un detenido, que se hallaba en sus dependencias, se tenía conocimiento de la reorganización del PCE en Sevilla. El 26 del mismo mes la policía hizo un registro en el domicilio de Florentino Muñoz, encontrando una máquina de escribir portátil y una maleta con abundante material de propaganda, entre el que destacan: 18 folios con catorce tipos distintos de eslóganes en cada uno de ellos; 2 folios con consignas; un llamamiento de cuatro hojas, de tamaño cuartilla, denominado El presente y el porvenir de la clase trabajadora. Voz de alerta a los grupos sindicales; un ejemplar de Reconquista de España, órgano de la Junta Suprema de Unión Nacional, edición de Andalucía, de cuatro hojas y sin fecha, en el que aparecen frases como "Una mancha en nuestra Historia: la División Azul»; "Un timbre de gloria: los guerrilleros españoles»; «La Unión Nacional para salvar a España", etc. También se encontró un ejemplar de Mundo Obrero. Órgano Central del PCE, edición de Andalucía, de cinco hojas, fechado en diciembre de 1943, cuyo editorial se titulaba "La Unión Nacional es nuestra primera tarea». A partir del interrogatorio a los detenidos se van sucediendo otros apresamientos que a su vez facilitan más nombres a la Brigada Político Social, hasta alcanzar la cifra de doce. De estos doce, el juez instructor dictó auto de procesamiento contra seis el 13 de abril de 1944. Después, el 7 de noviembre, el mismo magistrado pasó a plenario a cuatro de ellos, añadiendo además a Blanco y Castro, que ya estaban recluidos en la prisión de Alcalá de Henares, quedando formando el conjunto de encartados que fueron sometidos al Consejo de Guerra.

\section{CAUSA 661/1944. CONSEJO DE GUERRA DE 24 DE ENERO DE 1945}

Se trata esta Causa, aparte de por el número de implicados, por las fuertes condenas impuestas a algunos de ellos, la amplitud del material de propaganda anexo que se integra en la composición del procedimiento y por la relación con otro contra numerosos militantes comunistas del Campo de Gibraltar.

El 16 de mayo de 1944 se inició por la Brigada Político Social la recopilación de documentación que devendria en esta causa, informando que, como consecuencia de sus investigaciones, se habia descubierto una organización de individuos que estaban cometiendo actos contra la seguridad del Estado y emitiendo periódicos clandestinos como Mundo Obrero y Reconquista de España, en los que "se vertían graves insultos a su Excelencia el Jefe del Estado, al Ejército, a Falange y otras instituciones oficiales...", que repartían entre sus simpatizantes. El mismo reparto 
se había hecho con un manifiesto de tipo comunista, "salido a la luz pública el día primero de Mayo". Se habla también en esta comparecencia de la celebración de una reunión clandestina en un lugar cercano a la barriada de Heliópolis, donde se acordó la difusión de un documento titulado Hacía la insurrección nacional y la creación de material "corto" (símil pegatinas) con consignas de lucha, demandando la formación de comités de unidad obrera.

Al principio de este atestado existe un organigrama titulado ORGANIZACION COMUNISTA DESCUBIERTA EN SEVILLA, con diversos colores, recuadros, flechas de relación, etc. donde, de mano policial, se plasmaba la supuesta estructura del PCE en esta ciudad. En su vértice superior figura Antonio Sanz Carmona, del comité regional, que no fue localizado (para el Juez instructor, era el secretario general del expresado comité, como sucesor de Manuel Castro Campos, que estaba detenido y procesado en la Causa 337/44). De él dependerían la redacción de Mundo Obrero y los comités de Sevilla, Cádiz y Huelva. Del comité de Sevilla, formado por Ruiz Soler, como secretario político, Sevilla Panduro, como secretario de organización y Sánchez Galán, como secretario de agitación y propaganda, dependian los comités de los sectores de Triana, San Bernardo y Macarena. Al sector de Triana estaban subordinadas las células de las fábricas Hispano Aviación y Tablada, y tres más de índole territorial. Al sector de San Bernardo, la célula de la Pirotecnia Militar y de la Fábrica de Artillería y otras tres células de barrio. Al sector de la Macarena no estaba supeditada ninguna fábrica, pero sí las consustanciales tres células de barrio. En total, según este esquema, los componentes de todos estos grupos llegaban a un total de sesenta y cuatro personas, de las que cuarenta y seis declararon ante la Policía, constando en este legajo informes de conducta y de antecedentes políticos de todos ellos, emitidos a finales de enero 1945 por el comandante jefe de la Policía Urbana de Sevilla. También aparece en el expediente de esta causa una relación de la Jefatura Provincial de Falange Española Tradicionalista y de las JONS en la que figuran los cuarenta y seis encartados, donde se reflejan igualmente sus historiales. Según ella, veinticinco encartados carecían de "antecedentes políticos sociales en los archivos de esta Delegación». Sobre el resto se informaba que diez fueron miembros del PCE, o afines, antes de la guerra civil; cinco pertenecieron a sindicatos de izquierda; cinco eran simpatizantes de partidos de izquierda y uno actuó como interventor, por el Frente Popular, en las elecciones de 1936.

Al final fueron procesados treinta y tres, pues trece fueron puestos en libertad el 9 de septiembre de 1944 por el Capitán General. En el Consejo de Guerra fueron absueltos siete, aunque el fiscal había solicitado dos años de prisión para cada uno de ellos.

Los veintiséis inculpados que resultaron condenados por el Tribunal militar, son los que figuran en el cuadro siguiente: 


\begin{tabular}{|c|c|c|c|c|}
\hline Procesados & Condena & $\begin{array}{l}\text { Petición } \\
\text { M. Fiscal }\end{array}$ & Edad & Profesión \\
\hline Tomás Alvarez Blanco & 4 años & 6 años & 48 & Jornalero \\
\hline Vicente Blanco González & 2 años & 6 años & 28 & Carpintero \\
\hline Manuel Bozada Fernández & 6 meses & 2 años & 49 & Mecánico \\
\hline Manuel Cantelar Cresis & 12 años & 20 años & 35 & Fresador \\
\hline José Domínguez Orellana & 12 años & 20 años & 37 & Albañil \\
\hline Luis Expósito Ramos & 6 meses & 6 años & 26 & Ditero \\
\hline José Joaquín Fdez.Hermoso & 6 meses & 4 años & 32 & Carpintero \\
\hline José Gallo Caballero & 6 meses & 2 años & 48 & Mecánico \\
\hline Manuel González García & 6 meses & 2 años & 50 & Mecánico \\
\hline Pedro Iturriaga Gómez & 6 meses & 2 años & 38 & Metalúrgico \\
\hline Manuel León López & 20 años & 30 años & 32 & Empleado ferreteria \\
\hline Manuel Librada Gil & 6 meses & 2 años & 28 & Mecánico electricista \\
\hline Francisco López Barrera & 6 años & 20 años & 33 & Mecánico \\
\hline Manuel Morón Salgado & 6 años & 20 años & 31 & Fresador \\
\hline Angel Orellana Jiménez & 6 meses & 2 años & 45 & Albañil \\
\hline José Paradas Lozano & 20 años & 30 años & 28 & Jornalero \\
\hline José Fco.Pascual Vacas & 6 meses & 2 años & 26 & Ajustador \\
\hline Anselmo Ranz Gallardo & 6 meses & 2 años & 31 & Ajustador \\
\hline Antonio Rebollar Araujo & 6 meses & 2 años & 49 & Carrocero \\
\hline Salvador Ruiz Soler & 20 años & 30 años & 30 & Delineante \\
\hline Carmelo Sánchez Galán & 30 años & 30 años & 27 & Empleado \\
\hline José Sánchez Vadillo & 4 años & 6 años & 27 & Panadero \\
\hline José Sevilla Panduro & 30 años & 30 años & 31 & Albañil \\
\hline Manuel Talaverón Guiraut & 1 año & 4 años & 41 & Albañil \\
\hline Marcelino Vila del Río & 6 meses & 2 años & 34 & Peluquero \\
\hline José Villegas Pradas & 6 meses & 2 años & 46 & Tornero \\
\hline
\end{tabular}

En la formación de esta causa puede observarse claramente la técnica de acumulación de imputados. De los cuatro primeros, que interrogó la policía el 19 de mayo de 1944, obtuvo los nombres de otros y de éstos los de unos terceros, y así sucesivamente, hasta lograr el testimonio de los cuarenta y seis, que concluyó el 15 de junio. Por ejemplo, hay una diligencia en el proceso, de principios de junio, que dice: «En virtud de las declaraciones prestadas por... (Orellana, Domínguez, Vila, Sevilla y Paradas)... el señor inspector Jefe ordena se proceda la busca y detención de los siguientes individuos... (Sanz Carmona, León, Acosta, Ruiz Soler, ...un tal Valentín, otro conocido por Badillo que trabaja en HYTASA, un tal Baldomero, peón de albañil, ...etc.)".

La defensa, que ostentó el todavía teniente de Mutilados Eugenio Garrido Valero, suplicó que no se tuviera en cuenta que algunos de los procesados habian 
sido objeto de condena anterior por hechos derivados de la guerra y poseían antecedentes de pertenencia a organizaciones de izquierda durante la República. Interesó ahora cinco penas de 12 años, dos de cuatro años, otras dos de dos años y una de un año, para otros tantos acusados, pues «dada su inferior categoria en la organización subversiva", debian aplicárseles las penas correspondientes en su menor cuantía. Para los otros veintitrés procesados solicitó la absolución, «atendiendo que (...) solo han realizado un acto aparentemente humanitario y que esto y la lectura de periódicos subversivos, no está encuadrado en el art. $1 .^{\circ}$ de la Ley de 2-3-1943".

El tema de la necesidad de la unidad obrera es tratado en diversos documentos de los que constan unidos al procedimiento. Así, en el señalado con el $n$. ${ }^{\circ}$ 9 se hace un llamamiento «a todos los camaradas de los grupos de orientación sindical», solicitando que, después de un «largo y penoso periodo en el que han sido asesinados, encarcelados y desterrados los mejores cuadros de las organizaciones sindicales... es ya llegado el momento de que salgamos (...) y nos pongamos a la faena...". Se llamaba a un "acercamiento con los compañeros de UGT y CNT", con objeto de que los militantes de aquella de estas organizaciones que estén en minoría en un lugar, fábrica, etc., ingresasen en bloque en la otra, para potenciar la lucha de mutuo acuerdo. Instruía que se accediera al efecto a los directivos de gremios que "gozan de la relativa libertad que el gobierno fascista permite» $y$, en aquellos donde haya desaparecido esta clase de dirigentes, "poneros en inteligencia con los compañeros de mayor solvencia del gremio para que ellos efectúen el trabajo". Después siguen diversas consideraciones cuyo resumen de objetivos puede ser la consigna que cierra el escrito: “ii Viva la Unión de la clase trabajadora!!. Sevilla, abril 1944».

En el documento $n .^{\circ} 14$, anexo a este expediente, aparte de cursar las instrucciones para la discusión y aplicación del «histórico documento Hacia la insurrección nacionals elaborado por el partido comunista, se instruye sobre la logística de las reuniones, con desplazamientos de miembros de comités regionales a provinciales, de provinciales a sectoriales, etc., para que fuera bien comprendido por todos. Se insistía en la necesidad de formar en todos los sitios el partido de la Unión Nacional "con hombres honrados", en apoyar a los guerrilleros, en la redacción y difusión de Mundo Obrero y Reconquista, al menos una vez al mes. Se establecía la necesidad de reorganizar el umovimiento sindical (...) donde sea posible sobre bases enteramente unitarias, creando comités de unidad obrera que tomasen a su cargo la defensa de los intereses de los trabajadores. Donde eso no fuera posible, debía impulsarse la reorganización de la UGT....". La UGT debe plantearse la tarea de constituir comités unitarios con la CNT y cimentar en acciones comunes, prácticamente y sobre la marcha, la unidad sindical». Este tema de la unidad sindical es también tratado en el documento 30 , al señalar que la CNT de Barcelona destacaba en un manifiesto que, "después de la experiencia vivida, se impone la unión del proletariado en una sola central sindical», sin distinción de ugetistas, cenetistas o católicos, pues todos estaban en la «misma miseria y esclavitud». 
En poder de los detenidos se encontró dinero que, "apreciándose su ilegitimidad por ser producto de cotizaciones ilegales", se convirtió en Papel de Pagos al Estado, 26 pliegos por un total de 11.080 ptas. También fue requisada una máquina de escribir de la empresa sevillana García y Compañía, que Manuel León López utilizó para redactar la propaganda subversiva. Esta empresa, concluido el proceso pidió le fuera devuelta, lo que se realizó efectivamente en 5 de julio de 1947.

\section{5." CAUSA 262/1945. CONSEJOS DE GUERRA DEL 29 DE NOVIEMBRE DE 1945 Y DE 14 DE FEBRERO DE 1950}

Se refleja aqui por ser la continuación de un proceso anterior y por la cuantía de los castigos impuestos en algunos casos, con cuatro penas máximas solicitadas por el fiscal. De hecho se inició el atestado con la detención de varios militantes que no fueron incorporados a la causa 337/1944, para mantenerles vigilados estrechamente, poder conocer nuevos contactos y así hacer más amplia la redada contra presuntos miembros del PCE.

El primer juicio afectó a veinte de los veintinueve detenidos iniciales, puesto que seis de ellos no fueron encartados por no encontrarse motivo suficiente, y contra otros tres se ofició un Consejo de Guerra adicional el 14 de febrero de 1950 , dentro de la misma causa. Uno de estos últimos citados estaba recluido en el Hospital Psiquiátrico de Miraflores de Sevilla y los otros dos estaban huidos.

El defensor de los juzgados el 29 de noviembre de 1945 fue el capitán del Cuerpo de Mutilados Eugenio Garrido Valero, que aparecía desempeñando esta función muy habitualmente en estos años. En su intervención ante el Tribunal alegó que sus patrocinados no eran autores del delito de rebelión o auxilio a la rebelión, como imputaba el Ministerio Fiscal, sino solo en grado de tentativa, por lo que solicitaba 12 años de reclusión para García Dana, Gómez Villalba y Rincón Mena, si es que el Consejo de Guerra estimaba su actuación constitutiva de delito; 6 años pedía para Aliaga y Gutiérrez y 6 meses para otros ocho procesados, mientras instaba la libre absolución para los siete restantes, por no tener los hechos probados caracteres de delito.

La sentencia consideró incursos en adhesión a la rebelión militar a los cuatro condenados a las penas más importantes, y de auxilio a la misma a los restantes. En el cuadro siguiente se detallan los afectados y las condenas impuestas.

\begin{tabular}{|c|c|c|c|c|}
\hline Procesados & Condena & $\begin{array}{l}\text { Petición } \\
\text { M. }{ }^{\circ} \text { Fiscal }\end{array}$ & Edad & Profesión \\
\hline Antonio Aliaga López & 12 años & Muerte & 35 años & Mecánico \\
\hline José Avila Martín & 1 año & 6 años & 33 años & Mecánico textil \\
\hline Manuel Blanco Macías & 1 año & 6 años & 35 años & Guardia fábrica \\
\hline
\end{tabular}


(Continuación)

\begin{tabular}{lcccl} 
Procesados & Condena & $\begin{array}{c}\text { Petición } \\
\text { M. Fiscal }\end{array}$ & Edad & Profesión \\
\hline Julián Cabrillas López & 2 años & 6 años & 37 años & Jornalero \\
Manuel Carrasco Berlanga & 1 año & 6 años & 30 años & Tonelero \\
Fernando Carrillo Rodríguez & 2 años & 6 años & 26 años & Peluquero \\
Juan García Dana & 30 años & Muerte & 32 años & Pintor \\
Ant. . Ramón Gómez Villalba & 30 años & Muerte & 30 años & Pescadero \\
José Gutiérrez Muñoz & 6 años & 6 años & 29 años & Peluquero \\
Luis Jiménez de la Cuadra & 1 año & 6 años & 54 años & Barquero \\
Manuel Marín Rodríguez & 1 año & 6 años & 33 años & Jornalero \\
José Martínez Bernal & 6 años & 6 años & 29 años & Albañil \\
Manuel Moreno Ríos & 1 año & 6 años & 34 años & Jornalero \\
Juan Pérez Ramírez & 1 año & 6 años & 27 años & Chofer \\
Ricardo Rincón Mena & 20 años & Muerte & 36 años & Carpintero \\
Vicente Ríos García & 2 años & 6 años & 30 años & Jornalero \\
Bernardino Rodríguez Glez. & 2 años & 6 años & 36 años & Pintor \\
Rafael Rojas Rodriguez & 2 años & 6 años & 45 años & Ajustador \\
Francisco Rueda Rosa & 1 año & 6 años & 29 años & Fresador \\
Joaquín Sierra Carrasco & 1 año & 6 años & 36 años & Obrero textil \\
& & & & \\
Consejo de Guerra de 14-2-1950 & 1 año & 20 años & 40 años & Industrial \\
José Castro Montero & 2 años & 12 años & 57 años & Ajustador \\
Antonio Sanz Carmona & 2 años & 12 años & 41 años & Chofer \\
Antonio Torres Aguilar & & & &
\end{tabular}

El grupo detenido, según la versión policial, había desencadenado una activísima labor de agitación y propaganda, valiéndose de publicaciones como el periódico clandestino Reconquista de España o la Guía del Bibliófilo (que era en realidad un resumen de Mundo Obrero), donde "se insultaba al Jefe del Estado, al Ejército y a la Falange". También utilizaron "material corto" (consistente en trozos de papel engomado, un tipo similar a las etiquetas autoadhesivas actuales) y folios manuscritos o confeccionados a máquina de escribir. Destaca dentro de este expediente un ejemplar de Mundo Obrero, fechado en febrero 1945, de tamaño inferior a media cuartilla, con once páginas escritas a mano, en una letra pequeñisima pero muy clara, destinado a circular entre los militantes encarcelados en la Prisión Provincial de Sevilla. En este ejemplar, entre otras cosas, se incitaba a la huelga para el día de la caída de Hitler y se hacía un llamamiento a la unidad a UGT, CNT, sindicatos y todo el pueblo, para «aplastar a Franco y a la Falange». Esta "intensa campaña de agitación y propaganda», aseguraba la policía, «independientemente de su carácter punible, ha producido en algunos sectores afectos 
a la Causa Nacional una depresión moral como consecuencia del sentido exaltado en que están redactados y los augurios que se hacen para el caso de un cambio de régimen en España...».

Las acusaciones concretas contra los cuatro condenados a las penas de mayor entidad, probadas según la sentencia, fueron las siguientes: Gómez Vilialba, «fue designado para un cargo en la organización del PCE, de Sevilla, «que bien pudo ser el de secretario de agitación y propaganda del comité regional, o el de enlace entre el comité regional y el provincial, si bien parece ser que desempeñó este último... (subrayados nuestros), que fue lo que admitió ante el juzgado, además de haber intervenido como corrector en artículos publicados en Mundo Obrero. Ante el juez instructor se ratificó en lo declarado ante la policia, y que su finalidad «no era otra que seguir la corriente a la que el Destino le había lanzado...", calificándole dicho juez como "de inteligencia clara y fácil expresión, profundamente formado en la doctrina política comunista...", "alma del Partido en esta Capital», a cuya reorganización estaba dedicado. A García Dana se le consideró enlace entre el comité central del PCE y el regional de Andalucía y provincial de Sevilla. Ricardo Rincón habría designado los elementos que actuarían como estafetas en los comités provinciales; en su casa se almacenaban los periódicos clandestinos y cuanta propaganda hacía llegar a dichas estafetas. Y en relación con Aliaga subrayaba que tenía a su cargo la reorganización del "radio", de Triana, y "parece ser que ejerció también el cargo de enlace entre Triana y el comité provincial», del que sería "secretario de agitación y propaganda". Todos ellos negaron ocupar los cargos directivos que, dentro del PCE, se les acusaba ostentar, desdiciéndose así de lo que aparecia en las declaraciones ante la policía, aunque reconociendo la firma en ellas estampada. Gómez Villalba, ante el juez, declaró que la finalidad del PCE era "coadyuvar a la formación de un gobierno titulado de Unión Nacional, en el que habrían de tener ingreso elementos de todos los matices políticos" En similar manera se expresaron el resto de los detenidos en su comparencia ante el juez, rectificando las declaraciones suscritas ante la policía, que habían firmado, dijeron, para evitar ser maltratados.

De uno de los condenados, Fernando Carrillo, consta declaración ante la policía en la que refirió que en una reunión a la que asistieron, junto a él, cuatro militantes detentadores de diferentes cargos en el PCE sevillano, se había rechazado la organización de un grupo guerrillero en esta provincia, por la imposibilidad de llevarlo a cabo "en los momentos actuales". También se habría acordado que las peticiones a los patronos, por parte de los obreros, se realizara de una manera personal, para evitar la violencia de hacerlo colectivamente. No obstante se decidió la formación de células y troikas de Unión Nacional en cada lugar de trabajo y la agrupación de las constituidas en las fábricas, para ir creando los sindicatos de ramo. Igualmente se determinó que los individuos que hicieran traición al partido fueran castigados con la pena de muerte. Entendemos que esta última decisión no fue más que un ejercicio didáctico, pues no se ha localizado ningún caso en que se llevara a efecto, ya que el movimiento opositor en Sevilla tuvo un componente emi- 
nentemente pacífico. Pocos días después de esta reunión inició la policía la desarticulación de este grupo.

\section{6. ' CAUSA 287/1948. CONSEJO DE GUERRA DEL 22 DE FEBRERO DE 1949}

Las tres condenas a la pena máxima que se impusieron por el Tribunal, que en esta ocasión fueron ejecutadas, la grave desarticulación que se produjo en el movimiento opositor de Sevilla, la personalidad de los ajusticiados, las campañas a su favor tanto en Mundo Obrero como en la prensa internacional afín, así como la campaña efectuada en la capital hispalense contra esta sentencia mediante el lanzamiento de octavillas, pintadas, colocación de pegatinas en las paredes, etc. justifican traer aquí este proceso paradigmático de la década de los cuarenta en Sevilla.

Las detenciones se produjeron el 9 de febrero de 1948. Los comunistas aparecieron claramente a la luz pública, para aprovechar el descontento popular ocasionado por las inundaciones iniciadas en la mañana del martes 27 de enero. Se pretendió explotar la inquina de los damnificados contra el presunto culpable de la catástrofe, un ingeniero de la Confederación Hidrográfica del Guadalquivir, que habría ordenado talar en beneficio propio unos eucaliptus, que reforzaban el muro de contención del Tamarguillo en el sitio donde se produjo la rotura del cauce que inició la inundación. La censura, a la que estaban sujetos los medios de comunicación en aquellas fechas, implica que no comentaran nada alrededor de esta movilización, pero, indirectamente, el gobernador civil Coca de la Piñera se hacía eco de los rumores de que este malecón no se encontraba en perfecto estado, indicando que el bulo había corrido "sin tener en cuenta que, aunque en algunos lugares fueron cortados los árboles que antes existían, han quedado las raíces que dan consistencia al entramado que constituye el armazón del muro" ${ }^{3}$. Las aguas inundaron las zonas de Miraflores, Fontanal, La Corza, San Bernardo, Tiro de Línea, Porvenir, Palmera, etc., no llegando al casco antiguo por la realización de una brecha por fuerzas militares al sur de Heliópolis, que desalojó dos millones de metros cúbicos de agua directamente al río Guadaira.

Los perjudicados por esta riada realizaron una concentración de protesta ante el ayuntamiento, en la Plaza Nueva, para que no fueran desviados los fondos destinados a auxiliarles, como se comentaba había ocurrido con los librados en favor de los afectados por la grave inundación de 1947 que, decían, se utilizaron en el fastuoso recibimiento a Eva Duarte de Perón. La esperanza de que esta movilización sirviera a la propagación del partido llevó a los miembros del comité regional del PCE a situarse en un bar cercano, con objeto de dar las instrucciones pertinentes, a medida que iban evolucionando los acontecimientos. Pero ei movimien-

${ }^{3}$ Declaraciones publicadas en $A B C$, edición de Sevilla, el 1-2-1948. 
to de mensajeros entre la concentración y el establecimiento, alertó a la policía. Fueron detenidas alrededor de cien personas, bajo la acusación de pertenencia a dicho partido, quedando desmantelado el comité regional y parte de otras secciones, dejando al partido en Sevilla sin cuadros en libertad, una vez más, aun cuando no sin militantes de base. El aparato de comunicaciones, compuesto por máquinas de escribir, multicopistas, clichés y miles de ejemplares de propaganda impresa fue intervenido. Estaban en el lugar donde «tenian instalada la redacción de los periódicos clandestinos Mundo Obrero, Juventud, y Demófilo».

Este Consejo de Guerra, tuvo las características que se exponen en el siguiente cuadro:

\begin{tabular}{|c|c|c|c|c|}
\hline \multicolumn{5}{|c|}{ Procesados de Sevilla } \\
\hline Procesados & Condena & $\begin{array}{l}\text { Petición } \\
\text { M. }{ }^{\circ} \text { Fiscal }\end{array}$ & Edad & Profesión \\
\hline Balbino Alique Losa & 12 años & 30 años & 29 & Dependiente \\
\hline Francisco Arroyo Garrido & 1 año & 12 años & 44 & Albañil \\
\hline Enrique Bautista González & 6 meses & 6 años & 28 & Jornalero \\
\hline Luis Campos Osaba & Muerte & Muerte & 34 & Practicante \\
\hline Manuel García Armengol & 1 año & 6 años & 43 & Obrero \\
\hline Francisco Gómez Domínguez & 1 año & 12 años & 41 & Metalúrgico \\
\hline Carmen Gómez Ruiz & 6 años & 20 años & 31 & Mecanógrafa \\
\hline Antonio González García & 3 años & 12 años & 29 & Jornalero \\
\hline Olegario Guerra Utrera & 1 año & 12 años & 51 & Empleado \\
\hline Ana Gutiérrez Rodríguez & 2 años & 4 años & 24 & Manicura \\
\hline José Jiménez Acosta & 6 meses & 4 años & 44 & Chófer \\
\hline José Limón Berdejo & 6 años & 20 años & 26 & Mecánico \\
\hline Miguel Limón Berdejo & 1 año & 12 años & 29 & Jornalero \\
\hline Manuel López Castro & Muerte & Muerte & 42 & Metalúrgico \\
\hline Antonio Lorenzo Barba & 1 año & 6 años & 47 & Chófer \\
\hline José Mallo Fernández & Muerte & Muerte & 46 & Contable \\
\hline José Mendoza Mayo & 1 año & 12 años & 31 & Fogonero \\
\hline Diego Núñez Castillo & 6 años & 20 años & 32 & Jornalero \\
\hline Manuel Oca Cabello & 6 años & 6 años & 35 & Tornero \\
\hline Plácido Oliva Luna & 1 año & 12 años & 22 & Mecánico \\
\hline Alberto Rodríguez Pérez & 1 año & 12 años & 36 & Ajustador \\
\hline Joaquín Seda Pérez & 1 año & 12 años & 39 & Jornalero \\
\hline José Sierra Correa & 1 año & 12 años & 33 & Tornero \\
\hline Nicolás García Castro & 2 años & $\begin{array}{l}\text { No fue juz } \\
1-12-51\end{array}$ & do, $p$ & ermedad, sino hasta \\
\hline Emilio García Torrecillas & 1 año & $\begin{array}{l}\text { No fue ju } \\
\text { hasta } 17-3\end{array}$ & $\begin{array}{l}\text { gado, } \\
-51\end{array}$ & star en psiquiátrico \\
\hline
\end{tabular}


El delito de rebelión militar que se imputaba a estos detenidos era la organización del Partido Comunista en Sevilla, y en Huelva y su provincia, hechos que se consideraban probados. Con respecto a los principales imputados, Mallo, Campos y López Castro, los cargos que se les hicieron eran que ellos constituían el comité regional de dicho partido en Andalucía: Mallo, secretario general, ostentaría la suprema dirección y responsabilidad; Campos, secretario de agitación y propaganda, y López Castro, responsable sindical; que después de su formación en la escuela comunista de Capacitación de Cuadros, de Toulouse, fueron enviados por su comité central a España, donde entraron de forma clandestina para reorganizar el partido en Sevilla; que Campos y López Castro formaron parte de las partidas de bandoleros de Málaga, haciéndose cargo del $30 \%$ de las cantidades conseguidas en sus atracos, que remitían al titulado "jefe de estado mayor", Alfredo Cabello Gómez-Acebo. El fiscan destacaba en sus conclusiones que los tres primeros establecieron una serie de comités de carácter local, de sector o de barriada, de fábricas o empresas, hasta "terminar en las células formadas principalmente en los centros o lugares donde los obreros eran numerosos", para fomentar el malestar entre los trabajadores, induciéndoles a «formular reclamaciones caprichosas contra las empresas".

Además de los procesados de Sevilla que han quedado reseñados, en este Consejo de Guerra fueron condenados a diversas penas otros quince, domiciliados en Huelva y su provincia (Aljaraque, Gibraleón, Paterna del Campo y Escacena del Campo).

Los militares defensores, tanto de los residentes en Sevilla como en Huelva, interesaron la libre absolución de sus defendidos, con la excepción de Balbino Alique Losa, para quien solicitaron la pena de 6 años y un día. Sus argumentaciones exculpatorias fueron bastantes más extensas que las detectadas en procedimientos anteriores. Así, por ejemplo, el teniente Bermúdez (que defendía a catorce de los acusados), argumentó que no había más pruebas de que sus patrocinados ocuparan y representaran los cargos directivos a que se aludía en el proceso, que las declaraciones de los principales comprometidos. Se refirió, además, a que el «virus" del comunismo era fácil que arraigara en "un ambiente de incultura, de falta de moral privada, de desastre de principios fundamentales (...) como en un organismo enfermo es más fácil la enfermedad». Y concluía pidiendo el perdón para "estos hombres que no ofendieron sino a su propia persona», tratándoles de desgraciados cuyos cargos en la organización comunista solo existieron en la mente de los que los nombraron. El capitán Haya (defendiendo a diecisiete de los inculpados), señalaba en su alegato que, si existía en Sevilla un comité regional del Partido Comunista, no aparecía demostrada su existencia real en la exposición del fiscal y "aun cuando figuradamente y en papeles puede hablarse de él», en nada afectaba a sus patrocinados que no formaban parte ni teóricamente del mismo. Toda la acusación, seguía, se basaba en unas supuestas notas en poder del que se llama interventor (en otra parte del alegato se dice instructor) general del Partido Comunista, que habla de unos comités locales de los que no hay una sola prue- 
ba de su existencia. Y si se produjeron reclamaciones laborales en empresas, con o sin razón, y éstas implicaban una actitud subversiva «no cabe duda que sobra toda la legislación social tan avanzada vigente en España». Sobrarían la Dirección de Trabajo, las Magistraturas, los Sindicatos, los enlaces sindicales... y por ello, consideraba incompetente a un Consejo de Guerra para juzgar estos hechos. El capitán Lena, nombrado defensor de los principales encausados, tras destacar los méritos de la policía descubriendo una trama tan amplia, no encuentra una prueba tangible que enmarque a sus defendidos en la misma, ni que constituyeran el comité regional del PCE en Andalucia; que su único delito era el derivado de la "tenencia de los ejemplares de los periódicos clandestinos" y que este hecho no podía ser constitutivo de un delito de rebelión, sino de simples faltas. Al no existir delito no podía haber culpables. Mientras, en el caso de las dos mujeres encartadas que también defendía, solo ve un «delito de amor que será lícito o no, pero amor al fin". Por ello solicitaba la libre absolución de los procesados.

Campos, López Castro y Mallo, que se opusieron a ser representados en el juicio por un militar, entregaron sus propios pliegos de defensa, ante la indefensión en que decían encontrarse. Durante el juicio mostraron su disconformidad respecto a la competencia del Tribunal Militar y con la línea de defensa seguida por el capitán Lena, su defensor nombrado de oficio, al reafirmarse en que eran miembros directivos del PCE. La autodefensa, por escrito, a la que se ha aludido, no aparece en el legajo judicial correspondiente, aunque probablemente estuviera unido a él, ya que no aparecen en el expediente los folios comprendidos entre los números 951 al 992, ambos inclusive, situados inmediatamente a continuación de los de la sentencia. Este texto de autodefensa figura, presuntamente, en el trabajo inédito de José Cordero González, ¿De qué se nos acusa?. Constituia todo un ataque al Gobierno y a las instituciones. Los tres procesados protestaban por haberles incluido en la jurisdicción militar y por la denegación de una defensa civil. Reflejaban su orgullo y su honor por pertenecer al PCE. Descalificaban un régimen ufascista» reprobado por la ONU en septiembre 1946. Destacaban la españolidad de todos los acusados, en este y otros procesos, y de las figuras señeras del partido, frente a los «rifeños» de la Guardia de Franco. Denunciaban la situación de los trabajadores. Realizaban un análisis marxista de la Historia de España. Mostraban su aspiración a formar una España como la URSS. Criticaban la política económica del régimen: banca con balances fraudulentos, agricultura monopolizada por los terratenientes, industria y comercio en manos de monopolios. También arremetían contra el denominado rearme del Ejército, pues se hacia a costa del «hambre nacional", para mantener en un constante estado de opresión al pueblo, a la vez que presentaba intenciones agresivas contra la URSS y los paises de las nuevas democracias populares.

Las sentencias del Consejo de Guerra de 22 de febrero de 1949 fueron confirmadas el día 28 por el Capitán General, Ricardo de Rada, aunque dejó en suspenso «la ejecución de las condenas a pena de muerte, hasta tanto se resuelva por la Superioridad...» El Gobierno se dio por enterado a principios de marzo, produciéndose las ejecuciones el 12 de ese mes, día que fueron fusilados en ula tapia 
del costado derecho del cementerio", según refleja un escrito de la Jefatura Superior de Policía de Sevilla, de 11 de marzo de 1949. En el legajo que estamos comentando hay tres impresos, uno por cada condenado, de la Prisión Provincial de Sevilla, que resultan estremecedores: firmados por el director de la Prisión, el jefe de servicios y los funcionarios del vestíbulo, rastrillo y cancela, y con el «me hago cargo del recluso" del jefe de la Fuerza de Policía Armada, dicen en su texto preimpreso: «Permítase la salida de (...) reclusos anotados al margen por los motivos que en el mismo se expresan y previa comprobación de éstos, identificación de su persona...». En esta ocasión, al margen, en el lugar dejado en blanco por la imprenta, se señala como motivos "Para su ejecución".

\section{7.` CAUSA 23 Y 138 ACUMULADAS/1949. CONSEJO DE GUERRA DE 3 DE NOVIEMBRE DE 1949}

Estas Causas fueron contra militantes que eludieron las sucesivas "caídas" ausentándose de Sevilla, y que volvieron aquí con la intención de resucitar el comité provincial del PCE en Sevilla, que había quedado desarticulado por el proceso anterior. Entre la documentación que comprende este legajo destacan las noticias sobre una primera huelga de importancia en Sevilla tras la Guerra Civil, que tuvo lugar en Hispano Aviación, la cual, aun teniendo carácter de espontánea y estando motivada por un hecho puntual, constituyó un hito en la movilización laboral de la provincia.

El resultado del Consejo de Guerra fue el que se transcribe seguidamente:

\begin{tabular}{lllll}
\hline Procesados & Condena & $\begin{array}{c}\text { Petición } \\
\text { M. }{ }^{\circ} \text { Fiscal }\end{array}$ & Edad & Profesión \\
\hline Atalaya Hurtado, Antonio & 1 año & 6 años & 26 & Ajustador \\
Barragán Márquez, Fco. & 1 año & 6 años & 26 & Jornalero \\
Barrera García, Manuel & 6 meses & 2 años & 30 & Albañil \\
Caballero Barón, Manuel & 1 año & 4 años & 57 & Albañil \\
Cornelló Flores, José María & 4 años & 20 años & 29 & Albañil \\
Durán Rivero, José & 1 año & 2 años & 24 & Ajustador \\
Echevarría Reina, Francisco & 1 año & 6 años & 29 & Jornalero \\
Escalante Hidalgo, Antonio & 2 años & 8 años & 26 & Carpintero \\
Galeote Quesada, Juan & 1 año & 1 año & 41 & Cortador \\
García Castillo, Antonio & 5 años & 15 años & 42 & Jornalero \\
García Cazador, Antonio & 4 años & 10 años & 36 & Albañil \\
García Sanz, Manuel & 6 meses & 2 años & 25 & Mecánico \\
Iglesias Macarro, Leopoldo & 3 años & 15 años & 22 & Jornalero \\
Marín Fernández, Manuel & 1 año & 2 años & 34 & Albañil \\
Morales Iglesias, José & 1 año & 2 años & 47 & Albañil \\
Pastor Hurtado, Francisco & 5 años & 10 años & 35 & Albañil \\
Rodríguez Alvarez, Juan & 4 años & 10 años & 37 & Albañil \\
\hline
\end{tabular}


Según la Policía, dirigieron la "gran campaña de agitación, propaganda y otras actividades (...) en pro de la libertad de Mallo, Campos Osaba y Castron. Relata la diligencia policial que se puso en "constante, aunque discreta vigilancia» a Antonio García Castillo, comprobándose que udesempeñaba uno de los principales cargos en la dirección del Partido", descubriendo de esta forma a numerosos miembros de la organización comunista. Junto a Cornelló e Iglesias, habria constituido el comité regional. Esta vigilancia dio lugar a la detención de veinte personas entre los dias 14 de febrero y 22 de marzo de 1949, de los cuales fueron procesados y condenados a distintas penas los diecisiete reflejados en el cuadro. A los otros tres no se les encontraron indicios suficientes de responsabilidad criminal.

Como defensor de todos ellos actuó el capitán Eugenio Garrido Valero, que solicitó la libre absolución de todos los inculpados por uno concordar exactamente (la acusación) con la actuación que del sumario resulta a cargo de cada uno de los procesados" y por lo cual "no hay delito alguno imputable a mis defendidos".

En este sumario hay una abundante cantidad de material de propaganda encontrado en la calle por agentes del orden público (Policía Armada y Polícía Municipal), entre el 1 y 7 de enero de 1949. Son mayoría las hojitas de 16 por 5,5 centímetros con diferentes textos hechos con imprentilla como los siguientes: "Obreros. Unidad en la lucha contra el Franco falangismo"; "Fuera Franco y Falange del Poder ¡Viva la República!»; "Obreros todos a la lucha por nuestro bienestar"; "Abajo el terror. Sevillanos exigir la libertad de los patriotas Campos Mayo (sic) y Castro", todos ellos firmados por las Juventudes Socialistas Unificadas. A la vez aparecieron banderitas republicanas hechas pegando trocitos de papel; otros textos a máquina de escribir, de medidas 9 por 7 centímetros, editados mediante multicopista con declaraciones de la Pasionaria o de Antonio Mije, reafirmando la necesidad de la unidad de todos, fueran republicanos o no, para el combate en el interior del país; un ejemplar de Mundo Obrero de 10 de diciembre de 1948, y un folio, hecho a máquina de escribir y reproducido por multicopista titulado "El franquismo ha consumado un nuevo y... (ilegible) crimen. Los patriotas José Mallo Fernández, Manuel López Campos y Luis Campos Osaba han sido vilmente asesinados".

Como se ha comentado, entre los documentos incorporados en la formación de este legajo hay uno que analiza la huelga general del 25 de octubre de 1948 en Hispano Aviación (HASA), empresa en la que trabajaban más de 1.200 obreros. Se produjo, dice, como "consecuencia de la serie de injusticias y atropellos que con los obreros de dicha fábrica venía cometiendo el ingeniero alemán Pantroff, verdadero "amo" de la fábrica", que culminó con el despido arbitrario del maestro Pedro Riofrío, muy apreciado por su honradez y modestia. Los trabajadores, indignados, secundaron el llamamiento del "Sindicato Metalúrgico de la UGT", decidiendo declarar la huelga general de brazos caídos hasta que el despedido fuera readmitido de nuevo. Según continúa este boletín, se presentaron en la factoría el capitán general y el gobernador civil entre otras autoridades, que ante la fir- 
meza demostrada por los huelguistas se comprometieron a readmitir a Riofrío y a abonar los jornales perdidos. Pero, siguiendo el documento, esta rotunda victoria hizo ver a las autoridades las enormes repercusiones que podia tener en el fortalecimiento de la moral combativa del movimiento obrero clandestino, por lo que decidieron tomar represalias para sembrar el terror entre el proletariado sevillano, despidiendo al día siguiente a veintitrés empleados de HASA. El despliegue de fuerzas "terroristas" en rededor de la fábrica, la incomunicación de talleres y departamentos y la amenaza de nuevos despidos, creó el ambiente de miedo esperado y los trabajadores desistieron de ir nuevamente a la huelga. En el análisis de estos hechos, el comité del PCE destaca que las masas obreras se iban desprendiendo de la pesadilla fascista y se movilizaban para la acción, "con mucha más facilidad cuando se trata de problemas que a ellas las afecta directamente". Las células y militantes del PCE, por este motivo. debían vivir muy intensamente los problemas de sus campañeros de trabajo e ir a «la acción y la lucha unida, previa organización de los Sindicatos clandestinos de UGT». Reconocia, no obstante. que en las condiciones existentes no era posible «el triunfo completo de una acción de lucha" si no iba preparada con todo detalle, y que el fracaso había sido debido a la falta de preparación, a la que no se pudo llegar a tiempo por el carácter de espontaneidad que presentó la reclamación. Se estimaba que la participación general de los trabajadores, sin excepción ideológica, demostraba el inmenso campo existente para la unidad, la acción y la lucha. Su debilidad estaría en la falta de organización, pues habrian vencido si tras los veintitrés despidos no se hubieran dejado amedrentar, declarando nuevamente la huelga. Como nota final se instaba a su estudio y discusión por los militantes en sus respectivas células, para aprovechar la experiencia en futuras luchas.

\section{8." CAUSA 23/1950. CONSEJO DE GUERRA DE 19 DE MAYO DE 1951}

Puede considerarse como la segunda parte de la Causa 287/1948, por la personalidad del principal encartado, que fue ejecutado. Para la Brigada Político Social fue el único alto cargo que se libró de ser detenido y juzgado en aquella causa.

El movimiento opositor en Sevilla había quedado prácticamente desarticulado. Sin embargo, la policía tenía conocimiento desde detenciones anteriores, «a lo largo de ocho años", de la existencia de una persona que venía actuando como uno de los jefes y principales responsables del comité regional del Partido Comunista de Andalucía, como secretario de agitación y propaganda, y que ocultaba su personalidad bajo los seudónimos de D. Luis, D. Fernando, D. Felipe o D. Félix. Tras las últimas detenciones, por confidencias recibidas, la Brigada Político Social pasó a sospechar del abogado José Rodríguez Corento, de 33 años, funcionario por oposición de la Diputación Provincial desde el 1 de agosto de 1940, que venía ejerciendo el cargo de administrador del Hospital Psiquiátrico de Miraflores. Actuando con gran cautela, "por su condición y destino", que le situaba a cubierto de toda 
sospecha, se le sometió a discreta y constante vigilancia hasta tener la evidencia de sus contactos con elementos de la organización comunista. Detenido el 5 de enero de 1950, se le acusó de ser miembro de los comités regionales de las JSU y del Partido comunista desde el año 1946. Estando preso, en la madrugada del día 8 , intentó suicidarse en un calabozo de la Jefatura Superior de Policía, «produciéndose una herida en la flexura del codo izquierdo que deja al descubierto la vena mediana, sin herirla", de la que manaba abundante sangre, de pronóstico leve actual, según el facultativo del Hospital Central de Sevilla que le atendió. Lesión que se hizo con "una latilla del cordón de sus zapatos".

Su capacidad para eludir la detención por la policia había creado sospechas entre los militantes del Partido Comunista, entre ellos las de su máximo detractor, José Cordero, que especulaban sobre la posibilidad de que fuera el principal infiltrado en sus estructuras, gracias al cual se producían las desarticulaciones con tanta facilidad, pues solo se explicaban algunas detenciones si las fuerzas del orden hubieran tenido información de un alto cargo de la estructura comunista, que conociera con antelación a qué hora y en qué lugar iba a estar un determinado miembro del PCE. Estas suspicacias se mantuvieron aun después de su detención por la Brigada Político Social de Sevilla. Sobre julio de 1950, Radio España Independiente declaró a Corento «expulsado del PCE por ser un agente al servicio de la Policía", aunque este último argumentó que esta filtración radiofónica se había hecho con la intención de salvaguardarle ${ }^{4}$. En la cárcel, al parecer, disponía de una serie de privilegios, como tener abierta la celda hasta las 24 horas y poder deambular por sus instalaciones sin ninguna traba, manteniendo unas cordiales relaciones no solo con los altos cargos del centro penitenciario, sino con jueces que allí acudían y con los propios funcionarios, hasta el punto de haber «donado un libro de poesía para la biblioteca".

De cualquier forma, con las diligencias policiales aludidas se inició el procedimiento sumarísimo contra Rodríguez Corento y otros, por hechos que se habrían iniciado a partir de 1945 y que fueron juzgados en Consejo de Guerra, arrojando el resultado que figura en el siguiente cuadro:

\begin{tabular}{|c|c|c|c|c|}
\hline Procesados & Condena & $\begin{array}{l}\text { Petición } \\
\text { M. }{ }^{\circ} \text { Fiscal }\end{array}$ & Edad & Profesión \\
\hline Antonio J. Benítez Catalán & 6 meses & 6 años & 38 & Industrial \\
\hline Josefa Regalado Barroso & 4 años & 8 años & 37 & Sin ocupación conocida \\
\hline José Rodríguez Corento & Muerte & 30 años & 33 & Empleado \\
\hline
\end{tabular}

La defensa de los tres encartados fue ejercida por el capitán Eugenio Garrido Valero, que adujo que Corento sólo era autor de un delito de asociación ilegal, por

\footnotetext{
4 Archivo Histórico de Comisiones Obreras de Andalucía. Fondo Oral. José Codero González.
} 
cuyo motivo durante la vista, demandó una pena de 12 años y un día, rectificando así sus conclusiones preliminares en las que pedía su absolución, como consecuencia de «la prueba practicada» durante el desarrollo del Consejo de Guerra. También el fiscal modificó sus dictámenes previos, por el mismo motivo, pasando de una petición de 30 años de reclusión a la solicitud de la pena máxima. La defensa pidió para los otros dos condenados su libertad. Eran la criada de Corento y el suministrador de frutas y verduras del sanatorio, que conocieron y facilitaron sus contactos y difusión de propaganda, dice la sentencia.

En la primera declaración que hizo el detenido ante la Brigada Político Social, informó de que no había pertenecido a ningún partido político ni organización sindical con anterioridad al 18 de julio de 1936, y que habiéndole cogido el alzamiento en Madrid, al movilizarse su reemplazo, ingresó en la 37 Brigada Mixta, como auxiliar del miliciano de cultura. Terminada la contienda, y tras la estancia durante unos 25 días en un campo de concentración de los "nacionales", un aval por su conducta anterior a la Guerra Civil, emitido por varios socios del Ateneo sevillano, permitió su libertad y su regreso a Sevilla, tras prestar servicios como escribiente en la Auditoría de Guerra, por ser abogado, hasta octubre de 1939. Después ingresó de nuevo en el senvicio militar desde julio de 1940 hasta diciembre de 1941.

Sin embargo, por la Dirección General de Seguridad se certificó el 11 de enero de 1950, utilizando como fuente una declaración del propio Rodríguez Corento existente en archivos incautados en "Zona Roja", su pertenencia como miembro destacado del PCE al comité del frente del Tajo, responsable del hogar del combatiente en Aranjuez y director del periódico de la 45 Brigada, Adelante. Antes de la guerra, como miembro de la FUE había participado en movimientos estudiantiles de las Universidades de Sevilla, Madrid y Valladolid —de la que fue expulsado por «maniobras contra el director del colegio de Huérfanos» de esa plaza-, mientras le pagaba su carrera la Asociación de Huérfanos de Infantería. Sólo se dio de baja en las sociedades extremistas ante la amenaza del Ministerio de la Guerra de suprimirle la ayuda en sus estudios.

En septiembre 1946 - sigue su declaración ante la Policía-, trabajando ya en la Diputación Provincial de Sevilla, fue captado para donar fondos destinados a fomentar la lucha contra Franco. Después pasó a máquina propaganda de Alianza Democrática bajo los auspicios del amigo que le atrajo hacia el PCE. Más tarde, en junio 1947, Ricardo Beneyto Sopena (de quien dice el juez instructor que era el jefe del estado mayor de los guerrilleros de Málaga, Granada y Almería), le encomendó el cargo de secretario regional de agitación y propaganda, hasta que unos cinco meses después pasó a ocuparlo Luis Campos Osaba. Se le encargó, a cambio, la reorganización de las JSU como secretario general e instructor del PCE, logrando en ese cometido la formación de unos ocho clubes, de seis a ocho militantes cada uno, que realizaron emisión de propaganda, tiradas de un periódico llamado Juventud, etc. También se ocupó en este tiempo de dotarles de ayuda económica, con dinero procedente de «las partidas de bandoleros que pululaban 
por las sierras de Málaga, Granada, Campo de Gibraltar, Sevilla y Córdoba»; de proveerles de máquinas de escribir, imprentillas y material de escritorio; de volver a formar los cuadros de la organización clandestina, nombrándoles o sustituyéndoles, cuando los anteriores eran desarticulados por la policía, etc. En esta función permaneció unos ocho meses, hasta que en abril de 1948 ante la grave caída sufrida por el PCE se formó una nueva dirección, en la que pasó de nuevo a ser secretario de agitación y propaganda, mientras que José Cordero ocupó la secretaría de organización y un nombrado como "Andrés", secretario general, que por estar "quemado" acabaría desplazándose a otra región. En su nuevo puesto clandestino, Rodríguez Corento controlaba, e incluso realizaba, la emisión de propaganda, organizaba el traslado de la confeccionada en Jerez, daba consignas, buscaba alojamientos para los que precisaban cobijo, facilitaba documentaciones falsas para eludir la acción policial, etc. En los primeros días de mayo de 1949, se apartó de la organización. Por este alejamiento, por el abandono de la lucha contra el régimen, creyó quedar exento de toda responsabilidad por los hechos anteriores y, para romper con este pasado inmediato, se planteaba pedir excedencia en la Diputación y marchar a trabajar a Madrid. El juez instructor, además, le imputó que mientras fue administrador del Sanatorio Psiquiátrico de Miraflores, logró sustraer a la acción de la justicia a individuos peligrosos, facilitando su ingreso en este hospital bajo el subterfugio de ser sometidos a observación médica, ayudándoles posteriormente en su fuga.

Constituyeron, asimismo, objeto de investigación en este procedimiento las circunstancias que concurrieron para que entrara a trabajar en la Diputación Provincial y que le llevaron a ocupar el cargo de confianza que ostentaba en el sanatorio, dados sus antecedentes políticos y de combatiente en el «Ejército Rojo». La mencionada corporación aportó al juez instructor los certificados de buena conducta, de carencia de antecedentes penales y de adhesión al Movimiento que facilitó el Gobierno Civil de Sevilla el 26 de abril de 1940. En realidad Rodríguez Corento, cuyo padre, el teniente Rafael Rodríguez Mancera, murió en septiembre de 1924 al mando de la posición de Alalex (Tetuán), se valió de un certificado suscrito por varios jefes y oficiales ex-compañeros de su padre en el Regimiento de Infantería $n$. $^{\circ}$ 9, desconocedores de su actuación en "Zona Roja", para ser incluido en el turno de víctimas de la guerra en las oposiciones convocadas por la Diputación.

La ejecución no se demoró y el 25 de junio de 1951, a las 5 de la mañana, fue fusilado Rodríguez Corento en la tapia del costado derecho del cementerio de San Fernando de Sevilla, donde le había trasladado una dotación de la Guardia Civil. Fue inhumado en la fosa general del cementerio de disidentes.

El inicio de la "guerra fría» en el año 1949, y de la conflagración en Corea en junio de 1950, habia hecho de Franco un aliado fiel por su anticomunismo, y así el aislamiento internacional a que nos sometieron los vencedores de la II Guerra Mundial, fue superado, en forma definitiva, cuando la ONU revocó la condena que pesaba contra España el 4 de noviembre de 1950. Por ello, la condena de Rodrí- 
guez Corento a la pena máxima, y la ejecución de la misma, en una fecha tan tardía como la primavera de 1951, destaca en unos momentos en que el régimen franquista parecía que estaba inmerso en un proceso de mejora de imagen cara al exterior.

Consecuentemente, hay que considerar que el gobierno español descartó en esta ocasión la posibilidad de campañas de repulsa, tanto interiores como exteriores, ante el desorbitado castigo impuesto por un delito de asociacionismo ilegal, dada la información que habían difundido los comunistas de que Rodríguez Corento era un colaborador de la policía, fuera o no una estrategia para protegerle.

Esta situación representó una gran diferencia con las manifestaciones de todo tipo que se produjeron con las condenas a muerte, el 22 de febrero de 1949, de Mallo, Campos y López Castro, pues éstos fueron considerados héroes en la oposición a Franco. Además, entonces, las circunstancias exteriores eran todavía de reprobación del franquismo en todos los sectores, no solo los comunistas, mientras que la situación interior atravesaba el periodo final de liquidación de la resistencia armada que habían ejercido las guerrillas. Así no es de extrañar la ejecución de estas tres penas máximas, más aun al estimarse probado en la sentencia, que los dos últimos inculpados señalados habían formado parte de estas partidas, en la provincia de Málaga.

A los tres procesados, como después se hizo con Rodríguez Corento, se les acusó de ser autores de un delito de rebelión militar, tipificado en los números $1 .^{\circ}$ y $2 .^{\circ}$ del art. $1 .^{\circ}$ de la Ley de 2-3-1943 (B.O.E. 16-3-1943). Ley en la que se equiparaban a dicho delito, aquellas transgresiones de orden jurídico que tuviesen una manifiesta repercusión en la vida pública.

En el preámbulo de esta disposición oficial se establecía, como objetivo, crear una pieza disuasoria para que "en lo sucesivo nadie ose desviarse de una rígida disciplina social», tras la incorporación a la vida normal de los "que delinquieron influidos por propagandas y doctrinas erróneas". En la parte dispositiva se decretó que serían considerados reos de rebelión militar y penados con arreglo al Código de Justicia Militar, entre otros, los que se designaban en los dos primeros números del citado art. 1. ${ }^{\circ}$, que habian sido conculcados, según las respectivas sentencias, por los cuatro condenados a que nos venimos refiriendo. El n. ${ }^{\circ}$ incluía: «Los que propalen noticias falsas o tendenciosas a fin de causar trastornos de orden público interior, conflictos internacionales o desprestigio del Estado, Ejército o Autoridades". El n. ${ }^{\circ} 2$ comprendía: "Los que conspiren por cualquier medio o tomen parte en reuniones, conferencias o manifestaciones con los mismos fines expresados en el apartado anterior".

A Mallo, Campos y López Castro se les imputaron agravantes determinadas en el art. 192 del Código de Justicia Militar como eran "la perversidad de los delincuentes, sus antecedentes, la trascendencia del hecho y el daño producido y que hubieran podido producir a los intereses del Estado y de los particulares", y como 
consecuencia se les aplicó en su grado máximo la pena prevista en el artículo 288 del Código castrense.

De Rodríguez Corento se apreció que su participación había sido principal, "como cabeza de la actuación de cuantos elementos han venido actuando clandestinamente en los cuadros del partido comunista o en abierta rebelión contra los postulados del Estado, como acontece con cuantos han formado parte de las bandas de forajidos que han pululado por las sierras de esta Región...». En el contexto de la última parte del párrafo, los resultandos de la sentencia sólo se refieren a sus contactos con Mallo, Campos y López Castro y con Ricardo Beneyto Sopena, que fue jefe del estado mayor de los guerrilleros en la 9. ${ }^{\mathrm{a}}$ Región Militar. No se le acusó directamente de que formara parte de estos grupos. Por el carácter que se le imputó, de mando superior de los elementos rebeldes, se le aplicó el castigo inherente al art. 287 del Código. Habría que pensar si existió en el ánimo del tribunal que le juzgó un espíritu revanchista, como represalia por los sucesivos engaños que el encartado utilizó para llegar al puesto que ocupaba.

\section{CONCLUSIONES}

Aunque de la lectura de las declaraciones firmadas por los detenidos, ante la Brigada Político Social o la Guardia Civil, no se deduce que fueran obtenidas mediante violencia, pues en los textos no se observa el uso de un lenguaje de presiones o coacciones ni por parte de la policía ni por el juez instructor, por los testimonios de algunos de los presos la tortura física o psíquica siempre estuvo presente. A este respecto, como ejemplo, José Antonio Velasco Díaz ${ }^{5}$, detenido en 1945 contando con 19 años, comenta que estuvo incomunicado 30 días en los calabozos de la policia, sometido a palizas que le hacían sangrar por todas partes y que su hermana, que se llevaba su ropa sucia, tiraba directamente las camisas, llenas de sangre, porque estaban destrozadas. A su madre, que también estaba sometida a interrogatorio, le hicieron escuchar la tortura que hacían a otro detenido, haciéndola creer que era a su hijo, ocasionándola que se volviera loca y se intentara suicidar con un alfiler del moño que llevaba, clavándoselo a la altura del corazón. A Velasco le ofrecieron que, si cooperaba, su madre sería ingresada en el Hospital Psiquiátrico. Puso como condición verla antes y ésta no le reconoció.

Es ilógico suponer, tras la lectura de estos documentos, que las personas interrogadas estuvieran esperando que les preguntaran para involucrarse a si mismos, en hechos entonces delictivos, o para implicar a otros, algunas veces familiares muy cercanos, formándose así, gradualmente, el grupo de encartados en cada proceso. En los primeros años, en las comparecencias ante el juez, los procesados generalmente se ratificaban en lo que figuraba en sus declaraciones iniciales ante la Policía y solo algunos manifestaban no estar de acuerdo con la de-

5 Archivo Histórico de Comisiones Obreras de Andalucia. Fondo Oral. 
claración y que si la firmaron fue para no sufrir malos tratos por parte de los interrogadores. Posteriormente, a medida que iban pasando los años, la táctica era negar ante el magistrado, prácticamente, todo lo que figuraba en el atestado policial, salvo la firma, argumentando que las supuestas primeras declaraciones eran inventadas por la policía y los encartados no habían tenido más remedio que firmarlas para evitar ser torturados.

Por otra parte, en el contexto de lo que significaba en aquellos años la estancia en prisión hay que referirse al tormento que pasaban los internados, por las malas condiciones higiénicas, con parásitos de todo tipo, por hacinamiento y promiscuidad, por suciedad, por falta de alimentación, por el trato denigratorio a que eran sometidas las personas encarceladas, por el constante estado de terror en que eran mantenidos. Los presos de las Colonias Penitenciarias señalaban que preferían estar trabajando al aire libre, soportando las condiciones atmosféricas, antes que en la cárcel, pues al menos se sentían tratados con cierta humanidad. De los primeros tiempos hay el testimonio de Ricardo Limia: «en la cárcel te comían los piojos, no comías ná, te llevabas seis o siete meses comiendo lentejas por la mañana y por la tarde... yo era una calamidad, me caía, me tenían que sentar». Otro testimonio, de José Antonio Velasco, dice "nos desnudaban, nos pelaban, nos metían a ocho prisioneros en celdas con capacidad de uno, en unos colchones echados en el suelo, con un metro escaso para cada detenido, con un water y un lavabo para todos, sin mantas", etc. La comida, según este interlocutor, se componía de coles, nabos cocidos, gachas llenas de gusanos, prácticamente sin aderezar. José Cordero, en el tema de la comida, señala que en los quince meses que estuvo en la Prisión Provincial de Sevilla sólo comió al mediodia habas, procedentes de una finca del propio director de la cárcel. Al principio, en el momento de la cosecha estaban pasables, pero cuando transcurrió un tiempo, ya secas, acababan generando unos "cocos" o gusanos, que llegaban a producir una "nata" en la gaveta de la comida de hasta dos dedos. Por la noche, gachas, hechas de harina y agua, un engrudo, cuyo sabor intentaban disimular con una especie de sacarina sin refinar.

En las cárceles y en las Colonias Penitenciarias fue donde se instituyeron las primeras infraestructuras de resistencia política, que luego, al quedar en libertad los penados, trasladaron a los grupos del exterior, bien formando directamente parte de los cuadros dirigentes o aportando su experiencia en la base, incurriendo en un grave riesgo, porque las sentencias de los Tribunales militares, cuando alguno de estos ex-presos se juzgaba por otro delito, eran bastante más rigurosas que las aplicadas a los que carecían de antecedentes, y a la hora de acogerse a indultos esta reincidencia se constituía en un motivo excluyente, dándose el caso incluso de anular medidas de gracia ya concedidas.

La oposición sevillana, en el plano político, estuvo constituida fundamentalmente por el Partido Comunista. La generalidad de los inculpados en los Consejos

- Todos estos testimonios constan en el Fondo Oral del Archivo Histórico de Comisiones Obreras de Andalucía. 
de Guerra son considerados comunistas, aunque ellos se adscribieran en una época concreta a la Unión Nacional, teóricamente formada por izquierdas y derechas. Solo hemos observado la presencia de la UGT en la primera de las causas detalladas en este trabajo, $y$ en otra de menor entidad, que no se ha pormenorizado por la escasa relevancia de las condenas aplicadas, entre seis meses y un año, para trece procesados.

En estos años, la táctica utilizada por el PCE para la captación de simpatizantes se iniciaba en el entorno de vecinos, amigos y conocidos de otros militantes, especialmente si conocian que habian sido perjudicados en cualquier forma, ellos o sus familiares, por el alzamiento militar, pues el temor a que se produjeran infiltraciones de confidentes de la policía en sus filas hacía que la cautela fuera un factor predominante. El primer paso de aproximación se daba generalmente mediante la venta de papeletas de rifas, bajo un pretexto caritativo y solidario, de auxilio a los presos y a sus familias. La siguiente etapa era la de captación, que se iniciaba habitualmente con comentarios sobre la situación económica, social, política, e incluso deportiva, en España o la ciudad. Tras esta especie de examen, a las personas atraídas se les integraba en células compartimentadas, generalmente de tres componentes, asignándoles cargos para potenciar su responsabilidad. Se iba después a la formación de los sucesivos comités, locales, provinciales y regionales, en los que eran nombrados los secretarios general, de organización y de agitación y propaganda.

No se observan conflictos laborales de entidad en la inmediata posguerra. En los procesos vistos se detectan células del Partido Comunista o de Unión Nacional en grandes fábricas, pero que no comandaron un movimiento obrero significativo. De hecho las instrucciones que tenían sus componentes eran apoyar a las fuerzas remanentes de UGT e instar la unidad de todos los sindicalistas anteriores a la Guerra Civil. En este estudio se ha reflejado la huelga que tuvo lugar en octubre de 1948 en Hispano Aviación, por un hecho puntual, con un saldo de 23 despedidos, como medida cautelar y coercitiva de las autoridades. En otro procedimiento de los que hemos visto, se citan plantes en la S.A. Construcciones Agrícolas (SACA) el 14 de abril y 1 de mayo de 1947, cuya noticia surge cuando, en una indagación iniciada por otro motivo, la policía deja constancia del estado "de indisciplina social que se dejaba sentir en la empresa", donde se habían "producido hechos de marcado carácter subversivo". De resultas de esta investigación, después de detener a los "cuatro individuos más caracterizados" que podrian haber actuado como instigadores, no hubo resultados penales. Cordero González, cita otros plantes: en Construcciones Aeronáuticas (CASA), entre las pantaloneras de Brittany's, en La Exportadora, en los obreros portuarios, etc. ${ }^{7}$

No se observa una sistemática publicación ejemplarizante de las ejecuciones que se conocen que existieron en estos años. Así no se dice nada en la prensa de

7 En su obra inédita ¿De qué se nos acusa?. 
haberse llevado a cabo en el caso de Mallo y compañeros, ni en el de Rodríguez Corento, ni en el de ocho guerrilleros del Campo de Gibraltar fusilados al mismo tiempo que este último. Sí hemos visto, por el contrario, la aparición en la prensa sevillana de una nota del Capitán General de la 2. ${ }^{a}$ Región informando de haberse cumplido la sentencia del Consejo de Guerra contra el asesino del hijo, de 17 años, de un importante agricultor y ganadero de Sevilla, homicidio ocasionado en un intento de atraco ${ }^{8}$. Al culpable se le encontró responsable también de robo a mano armada a otro destacado miembro de la burguesía sevillana. Esta nota, más que por ejemplaridad, entendemos se publicó para dejar constancia del último párrafo de la nota: «Ambos hechos realizados por dicho individuo lo fueron aisladamente: es decir, que no tienen carácter de robos en cuadrilla ni formando partida, los cuales no existen en la provincia de Sevilla, donde la tranquilidad y la seguridad son normales".

Las condenas de prisión de cierta importancia impuestas en las causas vistas no llegaron generalmente a su término, pues hubo varios indultos en estos años cuarenta. Sin embargo, en los casos de condenas a castigos más pequeños, en virtud del tiempo que transcurría en la incoación del proceso, se observan tiempos de prisión preventiva superiores a la que después se impusieron ( $y$ ya se ha comentado el sufrimiento que la estancia en prisión suponía). En bastantes ocasiones, por otra parte, la dirección de la Prisión Provincial de Sevilla, recababa del juez instructor la justificación legal para mantener en cárcel algún detenido. En la cuantificación de los castigos, no hemos apreciado que se aplicara un criterio uniforme, pues para delitos similares, en unos casos se aplicaron las penas inferiores o las superiores previstas en el Código de Justicia Militar. Hay que considerar que, a pesar de las sucesivas proclamas de conciliación de «ineludibles imperativos de justicia con las normas de generosidad en que se inspira de continuo el Nuevo Estado"', siempre se mantuvo presente en la aplicación de los castigos los antecedentes de los inculpados por su actuación anterior, o durante, la Guerra $\mathrm{Ci}$ vil. En el detalle que se ha aportado pueden observarse las disparidades existentes para delitos similares.

Entre los indultos comentados destacó el de 9 de octubre de 1945, que concedió la remisión total de las penas a los que padecían castigo por el delito de rebelión militar u otros, cometidos hasta el $11^{\circ}$ de abril de 1939, justificándolo en que ya estaban excarcelados, en libertad provisional o por la redención de penas por el trabaio, alrededor del $90 \%$ de los que habían resultado condenados. Así hemos podido ver, por ejemplo, reos a los que se condenó a la pena de muerte por hechos anteriores a esta última fecha, conmutada en su momento por la inferior de 30 años que, beneficiados por otras rebajas sucesivas, representó su libertad a los 4 ó 5 años de la sentencia inicial.

${ }^{8}$ ABC, edición de Sevilla, y El Correo de Andalucia, 15-8-1946.

9 Preámbulo de la Ley de 1 de abril de 1941, de la Jefatura del Estado. B.O.E. de la misma fecha. 
Es habitual en las deposiciones de los defensores militares denotar la escasa importancia de los delitos juzgados, la reducida ortodoxia de los cargos que señalaban los fiscales y la amplitud de las condenas en relación con la ofensa infringida al Estado. Generalmente los tribunales sentenciaban reduciendo las pedidas por el fiscal; pocas veces se ha visto que las incrementasen y, solo en un caso, el presidente del tribunal aportó un voto particular contra lo decidido en el Consejo de Guerra, por apreciar que no había pruebas suficientes contra el procesado, que fue desestimado por la máxima autoridad judicial de la región.

Finalmente habría que destacar que, al final de los años cuarenta, la «paz» y la «tranquilidad cívica» que eran los objetivos de los rebelados contra la República, había logrado imponerse en Sevilla, a costa de eliminar en una u otra forma a los opositores a la dictadura: definitivamente, mediante cárcel o por el miedo, al sentirse vigilados hasta temer hablar, por no saber si los que les escuchaban informarían a la policía. 